\title{
CARTEL CONTROL: A RECORD OF FAILURE *
}

\author{
HEINRICH KRONSTEIN† AND GERTRUDE LEIGHTON†广
}

THE political and economic influence of the United States, as accentuated by World War II, emphasizes a national responsibility in contributing a wise solution to the problem currently presented by cartels and combines. ${ }^{1}$ The problem involves not only internal economic affairs; it is inexorably linked with United States policy towards the world at large. The proposals, ${ }^{2}$ therefore, of those who seek to substitute the English and Continental " system of "controlled" cartels and combines for the present American law, which strictly prohibits such monopolies, would seem to warrant careful consideration. More particularly, attention should be directed to the precedents upon which the proposals are based. Since these are mainly European in origin, it seems fitting at the close of one phase of European economic life to examine the nature of these precedents and to appraise, with particular reference to Germany, ${ }^{4}$ the development of one kind of cartel and combine "control."

A principal source of contention between proponents of prohibition

$\dagger$ Special Attorney, United States Department of Justice, and Profescor of Law, Georgetown Law School. The opinions expressed in this article do not necessarily reflect the views of the Department of Justice.

if Formerly Note Editor, Yale Laso Journal.

1. Distinguished from a "combine"-which may be defined as an economic entity, vertical in structure and comprised of corporations, partnerships or other business acsociations unified in a central authority by various legal devices-the "cartel" has been deserited by Rudolf Callmann:

"A cartel agreement adjusts the business activities of its members- of merchants of a particular field of industry or trade-to a given market. In particular it adjusts productive capacity in a given industry to the demands of the marlet, trying to correct the usual tendency of output capacity to outrun these demands. Such an adjustment among competitors limits or eliminates competitive freedom. A cartel is always a horizontal ascociation; . . . I define a cartel as:

a contractual association of legally independent entrepreneurs in the same or similar field of business formed with the intent, effect or potentiality of intluencing the market by means of regulation of competition."

See Hearings before the TNEC on Inzestigation of Concentration of Economic Porrer, 76th Cong., 3rd Sess. (1940) pt. 25, 13347 (hereinafter cited as HEarixgs).

2. See National Foreign Trade Counci, Inc., Messoranduas on Regulatory Measures Affecting Arserican Foreign Trade (1914) passim; Haussmann and Ahearn, The International Control of Cartels-Past and Fulure (1945) 20 Trougar 85; Perlins, Cartels: What Shall We Do About Them? (1944) 189 Harper's 570.

3. See Seager and Gulick, Trust and Corporation Probleus (1929) 663 el sez.; Hearrngs, passim, especially 13355; Kronstein, The Dynamics of German Carlels and Polerts I (1942) 9 U. OF CHI. L. REv. 643.

4. The absence of published decisions from Poland and Southeastern Europe generally, where administrative agencies have functioned pursuant to statutory authority without sustaining tribunal decisions, has confined much of the material that follows to German sources. The latter, however, are typical of the European development as a whole. 
and proponents of control is the manner in which the "public interest" may best be safeguarded. To the latter, the present world economy seems to have advanced beyond the stage of "free competition," and "control" appears more practical and realistic than prohibition; for control, it is urged, may restrain monopolistic abuse while encouraging industrial concerns in the promotion of activities favorable to the public interest.

Prohibition, on the other hand, assumes that the public interest is best served by the preservation of economic freedom and equal bargaining power in contractual relationships. It does not of course exclude the exercise of some control, but it requires that such control as exists be exercised by a government militant in its efforts to secure a free market; it requires the abolition of economic institutions which tend to inhibit, coerce or disrupt the natural balance of free competition. From this point of view, the claim of proponents of "control" that the fundamental contract relation is outmoded, appears somewhat naive. Doubtless a completely unregulated market is a thing of the past, but there is a difference of no small degree between "control" for the purpose of maintaining a naturally achieved economic balance, where individual as well as corporate activity is permitted free expression, and "control" designed to "make do" existing monopolies by attempting to purge them of their more aberrant traits.

But even if "control" in the latter and narrower sense were permitted to supersede prohibition, it would seem to require a formulation of objectives as clear and as definite as the principle of free competition implicit in prohibition. Once the latter is abandoned the substitute must be accompanied by a positive statement of public policy. In the absence of such legislative commitment, administrative and judicial agencies ${ }^{5}$ entrusted with control of cartels and combines have too often found themselves obliged to accept as the criterion of the public interest what cartels themselves have preordained.

One of the principal reasons for the failure of European control has been precisely this inability of legislative bodies to arrive at a satisfactory definition of the "public interest"; there has been little statutory guidance among the conflicting claims of adverse parties. As a result, the question was repeatedly raised: did the public interest lie with technologically weak members of a wire cartel ${ }^{6}$ which urged government support of the existing price structure, when a break in the market would have permitted technologically strong members of the cartel to obtain control of the few remaining firms? Did it lie with the German coal industry which in 1931 sought to "reform" backward coal

5. See infra p. 305 and p. 317.

6. Frankfurter Zeitung, August 6, 1931, p. 3; Callasann, Das Deutsche KartellRECHT (1934) 473 (hereinafter cited KARTELLRECHT). 
companies by government release of the entire industry from cartel obligations so as to force such companies out of business, if they failed to meet the industry's demands? ${ }^{7}$ Or was the public interest on the side of locomotive and railroad car manufacturers in their opposition to a German government-owned railroad which urged cartelization of these supply companies with a view to establishing higher prices by means of supply quotas? \& The French and German governments themselves were confronted with similar questions in having to decide whether to support national and international cartel price policies in respect to potash and phosphate industries, largely French government property, ${ }^{9}$ and in respect to the aluminum industry of which the German government owned 90 percent. ${ }^{10}$ Was it in the public interest to promote profits through high prices, or by favoring low prices to assure farmers a supply of cheap fertilizers and manufacturers cheap light metals? ${ }^{11}$ The list may be extended indefinitely, yet it suggests that once the automatic protection of public interest through the preservation of contractual equality was removed, agencies of control - became engulfed in a task of enormous intricacy, a task involving niceties of distinction which an agency could hardly hope to resolve without vigorous legislative assistance.

The basic divergence of these two views of control, centering fundamentally in disagreement as to the character of the public interest, as well as in diametrically opposed methods of securing its preservation, cannot be too strongly emphasized. Recognition of this dichotomy of viewpoint is essential to an understanding of the development of European cartel regulation; it makes particularly significant the disposition of "control" proponents to point repeatedly to the exemplary success of European regulation. ${ }^{12}$ For historical fact would seem to indicate clearly that the success is only exemplary in terms of a shifting, irresponsible concept of public welfare.

7. Frankfurter Zeitung, Jan. 25, 1931, p. 5, col. 1.

8. Id., Jan. 13, 1931, p. 5, col. 1 .

9. See statement of the Assistant to the Attorney General in documents attached to the consent decree in United States v. Deutsche Kalisyndiliat Gecellschaft (S. D. N. Y. 1924) In Equity; No. 41-24. See also re phosphates, Bulletin Quotidien, Paris, Dec. 13, 1933.

10. LiefianN, Beteil tgungs UND Finanzierungsgesellschifien (1931) 357. In 1931, as a further example, the Netherlands government yielded to the pressure of the Philips electrical firm and granted an extension in lamp patents which carried at least three years beyond the permissible statutory period, but assured Holland a proper share in the proposed extension of the international electric bulb cartel. See Franlifurter Zeitung, March 19, 1931, p. 5, col. 3, p. 6, col. 3 .

11. Thus it is frequently argued that only by means of cartel agreements in nitrogen, for example, could I. G. Farbenindustrie have made profits sufficient to support its valuable research in oil and rubber; that such research was of greater "public interest" to Germany than the interest of the farmer, a principal nitrogen consumer.

12. National Foreign Trade Councin, Inc., op. cil. supra note 2, at 111 et seg. 


\section{Judicial Latitude Permits Disintegration of Free Competition}

The collapse of free enterprise in Europe was due more to the failings of judicial enforcement than to the weakness of protective legislation. Legislative action had not been remiss, for the step from the closed economic systems of the pre-French Revolution period to free competition was the result of aw well-considered adoption of the liberal economic system..$^{13}$ Not inappropriately it was the legislature of Revolutionary France which first denounced interference in the "natural" balance of economic forces as a violation of the basic rights of mankind. ${ }^{14}$ Later the Criminal Code of 1810 decreed imprisonment for any one who individually or in coöperation with others negotiated transactions in order to obtain profit not resulting from "a free and natural balance of competition." 15 Notwithstanding these directions, as early as August 29,1833 , the criminal division of the Court of Paris ${ }^{16}$ declared valid, subject to certain conditions, a plan of price-fixing sponsored by a group of manufacturers. Although the Court found that in periods of depression the protection of industry was of superior importance to the protection of the liberal economy, the decision remained an exception until 1891, when the civil division of the Court of Paris first construed the Criminal Code as admitting a distinction between "good" and "bad" cartels: no objection to the cartel was allowed if its goal was "the defense of the common interests" of the people engaged in an industry. ${ }^{17}$ The new doctrine gained recognition rapidly. ${ }^{18}$ By 1911 the Cour de Cassation had adopted it, with minor modifications; the test of a "good" cartel now depended upon whether a "normal" price was sustained and whether this resulted in "normal" as opposed to "excessive"

13. See Boekm, WetTBewerb und MonopolizarrpF (1933) 319 et seq., especially 329. It should be mentioned that the author of this distinguished book, Franz Boehm, continued his efforts against monopoly in Germany even under the Nazi regime, for which activity he was excluded from office and deprived of income. Today he is Rector of the University of Freiburg, where he is joined by a number of courageous liberals, such as Eucken, Dietle, and Lampe.

14. Law of June 14, 1791 (Loi Chapelier), 3 Lors eT ACTES dU GouverneneNT 274 (1835); see Tchernoff, Ententes Economieues er Financlères: Cartels, Syndicats, Trusts, HoLdings (1933) 358.

15. Code PEnal (1810) art. 419. This provision remained in force until September 3,

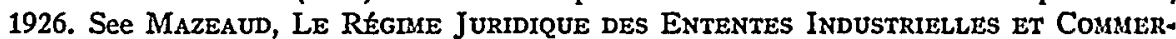
CIALES EN FraNCE (1928) 83 et seq., especially 84. Garraud, L'Etat actuel de la legislation et de la jurisprudence franfaises relatives a l'accaparement, da la spéculation illicile et aux coalitions (France, 1924) BULlETIN DE LA SOCIÉTE DE LEGISLATION COMPAREE 344.

16. Cour de Paris, August 29, 1833, digested in Industrie el Commerce, $\$ 424$ and note, 27 Dalloz, REpertorre MetHodique (1845) 791.

17. Cour de Paris, April 14, 1891 [1893] RecueIr Périodique de Jurisprudence (Dalloz) II, 70-1.

18. See e.g. Cour de Grenoble, May 1, 1894, [1895] Recueil Périodique DE JurisPRUDENCE (Dalloz) II, 221; Cour de Bordeaux, Jan. 2, 1900, [1901] id. II, 150, aff'g 'Trib. Comm., Périgueux, June 2, 1899. 
profit. ${ }^{19}$ The seemingly slight shift in this decision from "natural" price to "normal" price does not fail to betray, however, the fundamental regression from one attitude to another; from an economic system which assumes an objective standard capable of enforcement by the courts, to a system based upon a subjective standard derived from declarations of businessmen as to the reasonableness of their profits. As if unaware of the far-reaching effect of this development, the French legislature ratified on December 3,1926, what the courts had already accomplished..$^{20}$

In Central and Southeastern Europe events showed a similar development. Despite legislative prohibition ${ }^{21}$ against business agreements tending to raise prices to public disadvantage, ${ }^{22}$ the courts of the several Balkan countries dominated by Austrian law refused or were unable to curb the expansion of cartel agreements. By 1902 over fifty cartels of national importance were already functioning actively in Austria. ${ }^{23}$ The Austrian courts continually interpreted prohibitive statutes, admittedly designed to protect free competition, as rendering such agreements not void but unenforceable. ${ }^{24}$ And since courts would not therefore entertain suits, parties to agreements were enabled to achieve their purposes without court supervision or interference. Thus only dissatisfied parties willing to risk complete loss of their cartel

19. Chambre des Requêtes de la Cour de Cassation, Decision of MIay 3,1911, [1912] Recuen Périodique de JuRisprodence (Dalloz) I, 33; ere also previous decision of Tribunal de Commerce de Saint-Etienne, April 11, 1911, (France, Nov. 2, 1911) 12 G.1zcrre JUDICLAIRE ET COMDIERCLILE DE LYON.

20. This was brought about through amendment of the Criminal Code. Sze Mrzesud, op. cit. supra note 15 , at 91 .

21. During the period prior to World War I.

22. For the principal provisions see $\S 4$ of the Austrian statute dealing with "coalitions," where "any understanding between merchants, the purpose of which is to increase prices of . . . merchandise to the disadvantage of the public" was declared unenforceable. Law of April 7, 1870, [1870] ReIChsgesetzBlatr, No.43. On Czechoslovalian law generally,

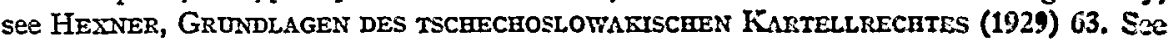
also Menzel, Die zoirtschafthichen Fartelle und die Rechtsordnung (Deutschland, 1895) 61 Schriften DEs Vereins fUER Soclalfolitir 23; Weiss-Wellenstein, Aerdeturng urd Vetcirheitlichung der Kartellgesetzgebung (Deutschland, 1928) 1 VERHuNDLUNGE: DES FUE:TFUni-

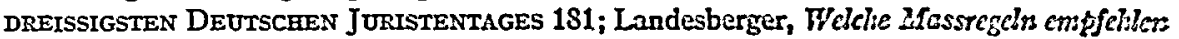
sich fuer die rechtliche Behandlung der Industrie Farkelle? [1902] 2 VenRaviduniog:i ocs SECHSUNDZWANZIGSTEN DEUTSCHEN JURISTENTAGES 294.

23. For a discussion of the development of Austrian cartels see Weiss-Wellenstein suspre note 22.

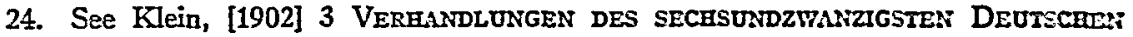
JURISTENTAGES 299. One of the earliest of the decisions, however, actually voided a cartel agreement: the Austrian electric light bulb cartel was adjudged without effect on the ground that since the poorer classes of society could scarcely afford the lowest prices established by free enterprise, artificial price elevation above that level could only result in harm to the public generally. See Decision of September 26, 1905, No. 10537, (1916) 8 (NEUE FoLGE)

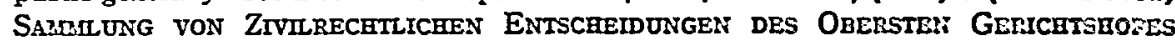
No. 3163. 
connections attempted to litigate in their own protection, a step soon found so regrettable in the face of ensuing boycott by cartel members ${ }^{26}$ that between 1878 and 1938 only eight cases involving cartels were brought into the highest court of Austria. In 1916 the court declared 20 that the question of harm arising from increased prices would not be considered, since in its opinion the cartel price:

“. . saved an important branch of the Austrian industry whose existence otherwise would have been threatened in a time of economic emergency. Nothing could be more advantageous to the public than the saving of an industry. Any individual disadvantage due to an increase in price would be off-set by removing from the cartel any illegality which might result from a price increase or from any inconsistency with good ethics." 27

In Germany the basic economic statute, the Gewerbeordnung of June $21,1869,28$ provided: "All trade is open to everyone, unless this statute provides exceptions from or limitations upon this rule." ${ }^{29}$ The Reichsgericht decision of February 4, 1897, ${ }^{30}$ however, adroitly deprived this declaration of its substance, and further entrenched the doctrine of "good cartels." ${ }^{31}$ The case involved an action for specific performance of a cartel agreement; the cartel management representing a Saxonian wood pulp producers' association, sought to hold a member to the purposes of the organization, which were "to prevent harmful competition among manufacturers and to obtain reasonable prices." 32 The opinion of the Reichsgericht expressed views familiar to American cartel proponents:

"If in any industrial field prices decrease to such an extent that the existence of a profitable industry is endangered, public welfare itself is in issue.... In its interest unreasonably low prices should be avoided. . . . Often the legislature itself tries to increase

25. Arbitration was the chief means by which such boycotts were made effective. Sce Kronstein, Business Arbilration-Instrument of Private Government (1944) 54 YALE L. J. 36, $42-4$.

26. Decision of March 28, 1916. [1916] JURISTISChe BLÄTTER 225.

27. Ibid.

28. [1869-70] BUNDESGESETZBLATT 245.

29. Section 1 of the Gewerbeordnung.

30. (1897) 38 ENTSCeEIdUNGeN DES Reichsgerichts in ZrviLsacuen (hereinafter cited R. G. Z.) 155.

31. The development in Germany appears to have been largely the same as in other countries, despite the common view that German cartels were originally governmentsponsored. See BOEHM, WeTtBewER3 und MONOPOL KAMPF (1933) 197, 317. Bochm's contributions to the whole problem of monopoly have been considerable. Dr. Kronstein is indebted to him for many ideas growing out of personal discussion of these questions. For German cartel law in general see KARTELLRECHT, passim.

32. See supra note 30. 
certain prices by protective tariffs or otherwise. It cannot therefore be contrary to public interest to permit owners of enterprises engaged in the same kind of business to combine for the purpose of preventing underselling and the decrease in prices resulting therefrom. This type of combination in self-defense is justified." 33

Thus, by disregarding legislative prohibition of cartels and monopolistic combines on the one hand, and by espousing the "good cartel" doctrine on the other, European courts in general soon found themselves in the position of having to deal as "control" agencies with much more involved problems than would have faced them under the legislative prohibitive system they had so successfully undermined.

\section{The Introduction of "ControL"}

Like the sorcerer's apprentice, courts had set in motion more than they knew how or had the power to stop. They were not endowed with the capacities of administrative agencies; the rules of procedure did not permit them to explore facts for themselves. As a result, it soon became apparent that they were forced to acquiesce to the able briefs of cartel lawyers, against which the less powerful and less well represented individual could scarcely prevail. Nor were the courts successful in preventing cartels and combines from applying to their own advantage legal devices originally designed for quite different purposes. Both the abuse of patent and trade-mark monopoly ${ }^{34}$ and the transformation of the meaning of "fairness" in business relations ${ }^{35}$ are well known. ${ }^{36}$ As a result, the position of monopolies improved; with the accumulation of decisions favorable to them, they came to possess that solidity which custom attaches to institutions by reason of their long and stable existence.

33. (1S97) 38 R. G. Z. 155, 157. The court also posed the following questions: "Doss an association of the character of the plaintiff violate the principles of commercial freedom enunciated by the Gewerbeordnung? Does an association of merchants, by fising minimum prices interfere with the legislative aim in guaranteeing commercial freedom in the interest of public velfare? Do contracts of the lind in issue illegally restrict the freedom of the individual?" Id. at 156.

34. See Hamilton, TNEC Rep., Patents and Free Exterpruse, Monograph 31 (1941) passim; Diggins, Trade-Mrarks and Restraints of Trade (1944) 32 GEo. L. J. 113.

35. Hearings at 13351-2. For discussion of misuse of the concept "unfair compatition" see Callalan, The Law of Unfair Coupetition and Trade-Mlares (1945).

36. In connection with shifts in original meanings and misuse of legal devices, attention should be called to the manner in which the old-fashioned German Verein or association, intended as a simple organization such as a Singrercin (Glee club), Tumrcreirs (Gym association) or other social club, was developed into a highly useful instrumentality by cartels and combines. A similar evolution affected the small businessman's Gesellsclefien mit bestlracr?ter Haftung (G.m.b.H.), or limited liability association, a type of business organization established by the statute of April 20, 1892 (Gesetz betr. die Gesellschaften mit beschroenlter Haftung). See Renner, Die Rechtsinstitute des Privatreckts und iare Sochile FUNKTION (1929) passim. 
As early as the beginning of the century the Austrian and German legislatures, and later the Parliament of Norway, ${ }^{37}$ sensing this course of events, appointed Enquêtes, or committees of investigation, to determine how responsible control or prohibition of cartels might be reestablished. ${ }^{38}$ These investigations did not result, however, in the resumption of a policy of prohibition, but in the establishment of administrative "control" agencies which were to supplement what little there was of existing judicial "control." So it was on November 2, $1923{ }^{39}$ that the German legislature created the first of the several European administrative agencies, authorizing it to regulate through licensing, membership control, and threat of dissolution, the activities and commercial relations of cartels and combines. An official statement accompanying the decree ${ }^{40}$ declared:

"There is a national interest in the re-establishment of freedom of the market, in opposing artificial restriction of production, excessive rates for alleged risks and excessive prices not justified by actual costs; there is a national interést in forcing producers and traders to rediscover their consciousness of duty toward the public." 41

Administrative control was divided between control offices and tribunals: the Reichswirtschaftsminister and the Kartellgericht (later the Reichswirtschaftsgericht) ${ }^{42}$ in Germany, and the Control Office and Control Council in Norway. These offices and tribunals belonged to the executive department of government, ${ }^{43}$ and in that position were sub-

37. The Norwegian commission on cartels was established by the statute of December 29, 1916, and the final report issued in 1922. See Tschierschky, Norwegischer Entwutrf ztb einem Gesetz ueber die Kontrolle von Zusammenschluessen, Monopolunternehmungen, u. s. vu. (Deutschland, 1923) 21 KARTELL-RUNDSCHAU 78.

38. Kontradiktorische VeraANdL Ungen Ueber Deutsche Kartelle (1903-1905); VERHANDLUNGEN DER OESSTERREICHISCHEN KarTELl ENQUETE (1912).

39. See Verordnung gegen Missbrauch wirtschaftlicher Machtstellungen, Nov, 2, 1923 (Kartell Verordnung) [1923] ReichsGesetzblatT I, 1067 (Hereinafter cited as KarTeLL VERORDNUNG). The Kartell Verordnung was subsequently amended by the Decree of June 14, 1932, [1932] REICBSGETZBLATT I, 289, and by the statute relating to the change of the Cartel Decree, July 15, 1933 [1933] ReichsGeSETZBLATt I, 487.

40. See Kartellrecht $673 \mathrm{et} \mathrm{seq.} \mathrm{During} \mathrm{the} \mathrm{period} \mathrm{immediately} \mathrm{prior} \mathrm{to} \mathrm{the} \mathrm{rise} \mathrm{of}$ dictatorships in Europe the distinction between rules of law enacted by executive and legislative power gradually disappeared. "Decree," therefore, is used throughout as meaning either of these types of enactments, but is not to be confused with the decisions of a court.

41. Ibid.

42. After 1938, the Kartellgericht was replaced by the Reichswirtschaftsgericht. Throughout this article the term "Cartel Court" is used to signify the German control tribunal generally, whether the Kartellgericht or Reichswirtschaftsgericht.

43. See Germany: Kartell Verordnung, § 11, suppra note 39. Norway: Statute of March 12, 1926. See Thagaard, Norwegisches Gesetz betreffend Kontrolle ton Konkurrenzeinschraenkungen und Preismissbrauch (1926) 24 KARTELL RUNDSCHAU 133. 
stantially strengthened by the sharp distinction between public law, governing relations between individuals and the government, and private law, governing the interrelations of individuals or business entities. Original jurisdiction of ordinary courts in no circumstances extended to questions of public law, except in criminal cases, thus leaving a wide area in which administrative agencies could function without judicial interference. And since judicial review of matters determined by the executive side of government, was limited to questions of jurisdiction, or legality of a statute, and to circumstances where such rejiew was specifically authorized, 4 the ordinary courts were bound to accept administrative determinations as conclusive. ${ }^{45}$

\section{"Control" through Adamistrative Agencies}

In granting these wide powers to administrative bodies, European legislatures were generally compelled to determine precisely what lind of monopolistic activity was to be regulated: the types of organizations and the types of transactions; and moreover what aims were to be accomplished by such regulation. ${ }^{40}$ In defining regulatory limits, the problem in draftsmanship was not lessened by the adaptable character of combines and cartels. Yet despite these difficulties several statutes show considerable agreement in the definition of cartels to be controlled. In Germany the latter were termed "contracts which establish obligations relating to production or marketing, conditions of delivery, methods of price-fixing," ${ }^{47}$ while according to Yugoslavian law "contracts, agreements and understandings between different enterprises or persons active within the same commercial fields" were included where

44. In a case decided June 14,1932 the Reichsgericht refused to review an administrative decision which, pursuant to statutory authority, ordered an individual to join a coal cartel. The Court stated that courts could not review the legality of measures of this lind; that they had always held that governmental acts were subject to review only within a limited scope and only if the statute itself provided that the measure could be reviewed. That was not found to be the case here. All that could be examined, the decicion continued, was whether the administrative agency had jurisdiction over a specific act in the field in which the agency was effective, and whether the character of the measure was lawful in any case. [1932] 30 KARTELL-RUNDSCHAU 565, 56 .

45. Influenced by Otto Mayer's Deutscaes Verwaltusgsrecat (1895), the courts interpreted Section 13 of the Gerichtsverfassungegesetz of Jan. 27, 1877, [1377] RercrsGESETZBLATT 41, to mean that the courts may not interfere with any decision of adminis-

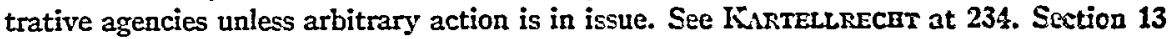
reads: "The ordinary courts have jurisdiction over all litigation of private and commercial character which is not expressly made subject to the jurisdiction of administrative agencies or administrative tribunals or of any special court." [1S77] REICrsoesetzBLAIT at 43. For discussion see lassar, Der Erstatrungsanspruch im Verwaltuigs-und Finasizecet (1921) 61 et seq.

46. See Ripert, Rapport présente au nom de la Commission des Ententes Eeonomigtses (France, 1932) 28 BULLETIN de LA SOctété d'Études LéGrsLATIVEs 253 el seq.

47. Kartell Verordnung, § 1. See supra note 39. 
"their purpose is to restrict, hinder or exclude the right to compete in production and marketing of products or . . . determine conditions of business or prices or rates." 48 But prior to World War II no agreement had yet been reached as to whether an actual rise in market price was a requisite feature of cartel activity, or whether the mere agreement to coöperate to that end sufficed to fulfill the statutory definition.

The scope of combines proved more difficult to encompass and the statutes are correspondingly diverse. On the one hand, Norwegian law subjected to control "industrialists who by virtue of their activities substantially influence price of goods or services in the Norwegian market ... and/or industrialists who are owners ... of concerns ... . under the decisive influence of a foreign enterprise or subject to a combination of foreign enterprises, provided that these affect substantially the prices of essential merchandise or services in one or several countries." ${ }^{49}$ German law, on the other hand, based its regulation less on the structure of organization than upon the monopolistic activity:

"Whenever conditions of delivery or the method of price fixing [applied by] enterprises (trusts, communities of interest, syndicates, cartels, conventions, or similar combinations) ... endanger public welfare and public economy because the latter exploit an economically dominating position, the Cartel Court on motion of the Secretary of Commerce may permit any party to a contract who suffers from such dominance by his contractee to withdraw from all contracts based on such conditions." ${ }^{60}$

As to the social purposes or aims which these definitions were designed to implement, the statutes usually contain only very general principles of "public welfare," 51 or "competition," ${ }^{52}$ or seek to "meet

48. Section 2, Par. 1, Decree of August 3, 1934 [1934] A.Z. No. 190. (In German literature the Yugoslavian statute collection is customarily cited A.Z. The full Yugoslavian title is Sslüzbene Novine, Gakoni. Ed.) This decree was authorized by Sec. 63 of the financial statute for the year 1934-5, and purported to ". . . clarify and . . . ease the economic conditions of the country." [1934] A.Z. No. 73, XVIII-168, p. 330. See Bilimovič, Das Kartellrecht Jugoslawiens (Deutschland, 1936) 3 ZEITSCHRIFT FUER OSTEUROPAEISCuES RECHT 67.

Under Norwegian law a cartel is an "understanding or cooperation of industrialists to regulate price, production or market conditions by formal or informal provisions provided such regulation affects the domestic market conditions; second, any agreement or any regulation having the purpose or effect in accordance with the above." Section $6,(1)$ and (2) of the Statute Concerning the Control of Limitation of Combinations and Abuses in Fixing of Prices, March 12, 1926. See Thagaard, Norwegisches Gesetz betreffend Kontrolle von Konkurrenzeinschraenkungen und Preismissbrauch (1926) 24 KARTELL-RUNDSCHAU 133.

49. Section 6, (3) and (4), Statute of March 12, 1926, (1926) 24 KARTELL-Rundsciruv, $133,134-5$.

50. KARTELl VeroRdNUNG, $\S 10$, see supra note 39.

51. Kartell VerordNung, $\S 4$, see supra note 39.

52. Norway: Statute of March 12, 1926, $\S 1$. See Thagaard, supra note 48, at 133. 
abuse in the fixing of prices." ${ }^{53}$ The path of administrative bodies was thus a precarious one; an analysis of their decisions involving regulatory devices seems to indicate that as the latter developed they generally failed to fulfill the declared legislative intent to re-establish "freedom of the market" and to resist "artificial restriction of production." 54

Licensing Power. ${ }^{55}$ Upon the theory that neither industry nor business may profitably run the risk of criminal prosecution, or the risk of having declared void its operational trade schemes, and at the same time seeking to afford some protection. to the individual, licensing has proved one of the most widely used regulatory devices. But though the fundamental purpose of the device is permissive (the sanction of cartel activity within limits), only in one instance did a legislature go so far as to grant full and exclusive power to a licensing authority to distinguish between legal and illegal cartel activities. Under a statute which generally prohibited cartels, the Yugoslavian Secretary of Commerce and Industry was permitted to determine at what point the "needs of production or trade" $s 5$ justified the existence of a cartel. Within this margin of tolerance cartels existing before the enactment of the statute in 1934 continued unrestricted and hardly disturbed. By an amendment of November 25, 1935, the combination of prohibition and discretionary licensing was replaced by a system in which the legality of a cartel rested not with the judgment of an official, but upon strict compliance with statutory registration requirements. ${ }^{37}$ Whether this worked a more effective control is left unanswered by official publications during $1934-35$, but the change would seem to indicate that after the experience of a single year discretionary sanction proved unworkable. Abandonment was at least significant.

Licensing authority in Norway, on the othęr hand, suffered not so

53. Id. $\$ 1$, at $137-9$.

54. See supra p. 304.

55. The analysis which follows deals exclusively with the attempted control of cartels. European experience has seen even less concrete effort in the control of single combines, despite the basic provision of the German Corporation Law, which has been copied in almost all Continental statutes: "Whenever a corporation endangers public welfare by the behavior of its management, violations of law or the principles of responsible leadership in business or othervise, the Reichswirtschaftsgericht on motion of the Reichswirtschaftsminister may dissolve the corporation." Corporation law of February 4, 1937, $\$ 288(1)$ [1937] RarcisGESETZBLATT I, 163.

56. See Section 1, Par. 1, Decree of August 3, 1934 [1934] A.Z. 1934 No. 190, which provides in full: "Cartels are prohibited. The Secretary of Commerce and Industry, however, after consultation with the council of ministers, may permit the establishment of cartels provided public interest under particular economic conditions justified their esistence. Such conditions may be found in needs of production or trade or in needs for a stabilization of business conditions, prices and rates." See Bilimoviè, supra note 4S.

57. See von Sladovic, Das Kartellrechl in Jagoslawien (1936) 3 ZEIrECBnHF DER AraDENIE FUER DEUTSCHES RECET 669, especially at 671. 
much from excessive discretionary power as from a statute which allowed industrial and manufacturing firms an easy means of evasion. Since the law required licenses only where the duration of contracts and agreements exceeded one year, ${ }^{58}$ it was inevitable that contracts contemplated "formal" termination within the statutory period, yet actually extended over a much longer term. That this proved a workable arrangement was due to the self-perpetuating nature of firmly established cartels. Continued operation independent of formal agreement was particularly successful where contact with the customer could be sustained indirectly through sales agencies and other organizations. It is understandable therefore that the majority of Norwegian Control Council cases have had to do, not with large industrial concerns, but with cartels of milk traders. For milk producers are rarely without customers, and since easy access to the latter tends to weaken dependence on cartel connections, milk cartels could only retain their members by binding them to formal agreements beyond the statutory year.

The single industrial case to come before the Norwegian Control Council, however, illustrates the type of international complication to which the licensing system may lead. The Norwegian firm, Norsk Hydro Elektriske Knadelstofaktiesalskab, applied for a license to adopt a nitrogen agreement entered into with I. G. Farbenindustrie. ${ }^{59} \mathrm{~A}$ sharp decline in Norwegian exports of nitrate fertilizers had resulted from the introduction by I. G. Farbenindustrie of a superior method of procuring nitrogen from the air. These circumstances, it was claimed, necessitated an agreement, drawn up in 1927, which provided for an exchange of shares and information, a release to Norsk Hydro of the technological discoveries made by the German firm, and for coördination of sales organizations. ${ }^{60}$ Recognizing its responsibility in shaping the relations of the Norwegian concern with an enterprise the size of I. G. Farbenindustrie, the Control Council undertook to preserve the prestige and power of Norsk Hydro within the framework of the cartel. ${ }^{01}$ Among the several changes proposed, and ultimately accepted by I. G. Farbenindustrie, was the allotment of a higher production quota to the Norwegian firm.

In approving such an agreement, the Council had to determine, as had the licensing bodies of other countries, the suitableness of these private market regulations, and to anticipate the moves, successes, or failures of foreign business concerns with which the domestic firm must now coöperate; it had to note what prices, production quantities,

58. Statute of March 12, 1926, § 16; see Thagaard, supra note 48, at 137.

59. See First Report on Effectiveness of Norwegian Cartel and Trust Legislation; July 1, 1926-Dec. 31, 1927 in (Norge, 1928) 1 TRUSTEONTROLLEN.

60. Ibid.

61. Ibid. 
market distributions, were commensurate with the good of the nation as a whole. Yet in the performance of this duty the Council was without an objective standard; and who could say in the light of this that the Council had erred in attaching the fortunes of Norsk Hydro to the vast nitrogen resources of the German company, instead of considering more critically the benefits of such an agreement to the Norwegian farmer?

Doubtless the international aspect of the situation was responsible in part for the readiness of the Control Council to approve the application. Having once acquiesced to the purposes of the private company, it was but a short step for the Council to assume the defense of Norwegian private interests in the conflict of world industry. ${ }^{62}$ Moreover a government, through its control agency, could hardly be expected to resist the temptation to exploit the political advantage of such international connections. Ironically enough, in this instance the German political maneuvers in industrial guise won out in the end, and I. G. Farbenindustrie at length secured in Norway itself the very plantsand production quotas - it had conceded to Norsk Hydro.

In a more restricted capacity, licensing also served to inhibit specific cartel rules and regulations. Section 9 of the German Cartel decree of $1923,{ }^{63}$ for example, requires a license wherever a cartel directs, for the purpose of a general boycott, the exclusion of any individual or corporate entity from the business, or the severing of his or its connection with a necessary source of supply. Until shortly after 1927 the Cartel Court, ${ }^{64}$ adhering to the cartel decree of 1923 , refused licenses wherever a cartel rule could be made to serve monopolistic purposes. The now classical decision of February 17, $1927^{65}$ denying a license to the Stahlwerksverband, which had sought to boycott a concern for refusal to join the cartel, illustrates the vigor with which the decree was at first upheld:

"The individual trader is no longer able to act in the interest of consumers through effecting price changes. This trend leads finally to monopoly and to dangerous conditions where consumers'

62. According to private information from leading cartel members, at the request of French nitrogen producers, the French government required nitrogen importation licences solely for the purpose of strengthening the position of French firms in international cartel negotiations; the German government, instigated by I. G. Farbenindustrie, threatened a 100 per cent increase in German tariffs on nitrogen in order to preserve the international cartel created to further I. G. Farbenindustrie's nitrogen interests.

63. See Kartell Verondnung, supra note 39. See also Norwegian Statute of March $12,1926, \S 21$, par. 2, cited supra note 48 .

64. The Reichswirtschaftsminister was in fact the licensing authority, but from his decision appeal could be taken to the full Cartel Court. See Knrreul Veronorru:ig, 89, supra note 39.

65. See (1927) 32 Dedtsche JuRisten Zertung 724. 
interests are unprotected against price dictatorships of producers. The fact that almost all iron merchants have accepted the rules of the organization [Stahlwerksverband] is no argument in favor of these conditions, since there can be no doubt that many wholesalers have joined the organization only because they faced the overwhelming power of the Stahlwerksverband whose economic retaliation they feared." 66

But the substance of later decisions of the same court is very different. The trend appeared to be in the direction characteristic of the ordinary civil courts, ${ }^{67}$ and with the same result: the longer the concept of the "good" cartel prevailed the more often the Cartel Court came to support the contentions of the cartel as against customer and consumer. In a comparatively recent instance, ${ }^{68}$ the Reichswirtschaftsminister granted a license permitting the licensee to boycott a non-cartel member who had resisted pressure to join the licensee-cartel. This stand was taken on the basis of a 1935 Cartel Court decision which had declared a cartel must be free to exercise all necessary pressure whenever non-cartel members, after suitable invitation, refused to join a cartel. ${ }^{69}$ Enforced membership was even further encouraged by issuance of conditional boycott licenses, which provided specified periods of time within which "offenders" might join voluntarily. The underlying theory was simply that the commercially weaker members of a cartel could not afford the drop in price which would result if efficient and commercially strong firms remained outside the cartel organization. ${ }^{70}$ There would appear to be, therefore, little doubt that the Cartel Court submitted to various pressures of commercial groups, nor that by degrees the licensing device, originally conceived as a weapon against cartels, at length became a weapon in the hands of the cartels themselves.

It may well be argued, however, that the general reversal of the Cartel Court's policy was not a wholly typical outcome of a system of administrative "control," but was due to the special influence of German National Socialism, which sought to exploit established cartel power. Admittedly the political philosophy of totalitarianism was a contributing factor, but that philosophy seems to have come into its

66. Id. at 726.

67. See infra section on Judicial "Control."

68. Decision of August 14, 1940, (1940) 38 Kartell-Rundschau 339.

69. Decision of March 5, 1935, (Germany, May 15, 1935) 12 Entscheidungen und Gutaceten des Kartellgerichts (hereinafter cited E. uND G.) Decision No. 299.

70. Boycotts were not only instrumental in compelling outsiders to join cartels but also in preventing members from cancelling their cartel membership. In 1936 a boycott license was granted upon the withdrawal of a member, on the ground that the cartel had asked nothing unreasonable of the member, who could rightfully be expected to return. Decision of November 17, 1936, (1937) 35 KARTELL-RÜNDSCHAU 30. 
full power after administrative agencies had begun to acquiesce to the pressure of "good" cartels." The political phase of cartel activity, as already indicated, ${ }^{72}$ was the last phase rather than the first; resultant rather than causative. Moreover, the comparable rise of strong organizations having a deleterious effect on "control" agencies in Switzerland ${ }^{73}$ can hardly be traceable to German political philosophy.

Nevertheless, a startling example of political manipulation of licensing is exhibited by German decisions involving the right of German cartels to boycott coöperative associations. Disputes arose in connection with the claim of the coöperatives that they were entitled to resell their products exclusively to their own nembers or to retailers associated with them, and were not required to permit German producers to encroach on this trade. ${ }^{74}$ The last of the cases, arising in October $1938,{ }^{75}$ involved a craftsmen's coöperative which customarily purchased all supply materials for each member. Upon solicitation by the coöperative the German cartel refused to sell, and sought instead a boycott license from the Reichswirtschaftsminister on the ground that such a coöperative proved injurious to other wholesalers with whom the cartel management desired to remain on good terms. In the opinion of the Cartel Court, to which the case was referred, the contention of the cartel was not well-founded. With exceptional foresight, judgment was rendered in favor of the defendant upon the ground that Section 9 to was intended to protect "genuine competition against the abuse of private power." 77 But the full significance of the decision became only too apparent in the light of subsequent developments. For as part of a policy of establishing a cartel of even larger proportions, comprising both wholesalers and the coöperatives themselves, the German government through its administrative agency encouraged the activities of the coöperatives, as long as they did not in actual fact compete with wholesalers. In the event that they did so, in Norway as well as in

71. See Decision of Cartel Court, March 5, 1935, supra note 69; Norsh Hyilro care, supra note 59; Decision of the Court of Paris, supra note 17. Compare also eases cited infro notes 87 and S8; see Kronstein, The Dynamics of German Cartels and Patents I (1942) 9 U. OF CHI. L. Rev. 643.

72. See discussion of Norwegian Control Council and the Norsl-Hydro case, stspre p. 308 .

73. See infra pp. 323-1 the Swiss decisions of February 12, 1936, Schweiger-Haucer gegen Schweiz. Tabakverband, [1936] ENTschemonigen des Scawelzerische: BundesGERICETS (hereinafter cited B. G. E.) II, 97, and of October 6, 1936, Berner Schachtelläsefabrik, A. G. und Fromagerie Le Castel, S. A. gegen Schweizericche Küceunion, [1936] B. G. E. II, 276.

74. See Kartellrecht at 405 et seg.; for discussion of German coüperatives cse Gierke, Das Deutsche Genossenschaftsrecht, (1913).

75. Decision of October 31, 1938, (1939) 37 Kartell-Roirdscrud 21.

76. KARTELL VERORDNUNG, supra note 39.

77. (1939) 37 KARTELL-RUNDSCHAU at 27. 
Germany, ${ }^{78}$ they then became subject to discrimination through the licensed boycott. ${ }^{79}$

Somewhat removed from the field of market regulation was the custom of permitting cartel members to utilize licensing as a means of mutual blackmail. In a controversy between Lorenz, A. G. ${ }^{80}$ together with the Philips Company of Eindhoven, and Telefunken A. G. (controlled by A. E. G. ${ }^{81}$ and Siemens), a cartel arbitration tribunal had ruled that by the provision of the cartel agreement between these opposing groups, the Philips (Eindhoven) group could not supply radio material and equipment to Philips, G. m. b. H., a German subsidiary of the Netherlands firm. ${ }^{82}$ Upon the petition of Philips (Eindhoven) and associates, the Cartel Court declared that such an arbitral decision amounted to a boycott of Philips, G. m. b. H., and that if the German concerns led by Telefunken A. G., insisted upon its terms, they would be required to secure a license in accordance with Section $9 .{ }^{83} \mathrm{But}$ within a few days of this decision, not unexpectedly, a new cartel agreement appears to have been drawn up between the major parties. ${ }^{84}$ Thus the Philips (Eindhoven) group was permitted to expand and improve its position within the cartel structure at the expense of the licensing system.

The principles enunciated in the Stahlwerksverband case could not withstand repeated contrary rulings of this type. Nor could they stem the rapidity with which cartel organizations, supposedly curbed and controlled, gained a position of preëminence, whence they could impose their own code of business on commercial transactions generally. Once the power to regulate market conditions was assured, it was within their means to prescribe who had qualifications to do business and who had not. ${ }^{85}$ They could determine the business experience prerequisite

78. See (Germany, 1930) 7 E. und G. Decision No. 130. (March 30, 1930). For discussion compare KARTELLRECHT 383 et seq.

79. Licensing was also used to keep out foreign competition. See American-Brilish Tobacco Co. case where the Norwegian Control Council licensed a boycott of an AmericanBritish enterprise. [1928] 12 Trustrontrollen, Decision of July 5, 1928.

80. A Berlin concern under the control of International Telephone and Telegraph Company.

81. Namely, Allgemeine Elektrizitaetsgesellschaft.

82. See Frankfurter Zeitung, March 18, 1931, p. 10, col. 4.

83. Kartell VeroRDNUNG, supra note 39.

84. The grant of a license to boycott Philips, G.m.b.H., if exploited, would have clearly terminated the balance of power between the two radio empires. Despite the hope of leading commercial papers (especially the Frankfurter Zeitung) that decisive results would follow from the Cartel Court decision, the continuance of the old balance seems to indicate that the parties had reached a compromise.

85. Notwithstanding the resistance of the Cartel Court, it was inevitable that such power was eventually put to political uses. See Decision of Nov. 22, 1935 (Germany, March 11, 1936) 12 E. und G., Decision No. 372; Kronstein, The Dynamics of German Cartels and Patents II (1942) 10 U. of CHr. L. REv. 50; infra section on Totalitarian Economy, p. 328. 
to engaging in certain fields of commerce, ${ }^{85}$ what persons were entitled to engage simultaneously in both wholesale and retail trade, ${ }^{87}$ who was entitled to be a producer and who a wholesaler. $\$ 3$ Yet nothing in this development may be regarded as unlooked for, given the premise of a "good cartel" whose interests are deemed identical with those of the public. It does not then appear illogical to permit such organizations to set the minimum standards of business nor to encourage an enlargement of their membership.

Power to dissolve cartels. By the decree of November 1923, the Reichswirtschaftsminister was authorized, in addition to issuing licenses, to dissolve cartels altogether upon petition and to annul any part of a cartel agreement, subject to review by the cartel court. ${ }^{5}$ But all the eight dissolution cases filed with the Reichswirtschaftsminister between November 1923 and October $1926^{\circ 3}$ terminated in compromise, including two cases dealing with proposed annulment of certain business practices which the defendant cartel had advocated.92 Moreover, in the years of economic depression that followed, German reports showed no instance in which a cartel had been dissolved under the decree, nor in which even a specific provision of a cartel agreement had been abrogated. ${ }^{92}$ The amendment of the decree in $19322^{23}$ to permit the Reichswirtschaftsminister to exercise control without reference to the Cartel Court, failed to improve the situation, though it is reasonable to suppose that many cases now without tribunal hearing went unreported. Yet what published decisions there are, together with the available decisions of other countries, ${ }^{04}$ would seem to indicate a weak administrative policy. Despite the repeated claim that governments secretly exercised a determinative influence over cartels through contact with personnel ${ }^{95}$ and despite the claim of the Reichswirtschafts-

86. See KartellRecet 413.

87. Decision of Nov. 10, 1924, (1924) 22 KARTELL-RundschuU 407.

88. Decision of July 24,1925 , (1925) 23 KartelL-Rusdscinu 434; see also as to the sufficient "reliability" of persons or firms engaged in trade, Decision of Jan. 30, 1931, (1931) 29 KARTELL-RUNDSCHAU 278.

89. See Kartell Verordnung, supra note 39, Section 4 (Dissolution of Cartels).

90. See 21-24 KartelL-RundsCEAU (1923)-(1926).

91. Of the latter, one concerned cartel-dictated sales terms whereby the seller was relieved of liability in event of failure to deliver goods within a specified time. See Goldunum, Die Neue Kartellverordnung (1930) 169. The other, a gold clause case resulted in a compromise owing to termination in 1927 of the inflationary period upon which had been based the cartel's insistance on preservation of the disputed clause.

92. See 25-31 KARTELL-RUNDSCHAU (1927)-(1933).

93. Kartell Verordnung, §9, Par. 4, as amended June 14, 1932 [1932] ReicisGESETZBLATT I, 289.

94. See supra note 59, at 77; Kelemen, Eine Krilit des ungarisclicn Karlellgeselzes (1933) 31 KarTELL-RUNDSCHAU 184.

95. See statement by Dr. Curtius, before the Reichstag in 1927 (34Sth meeting). Parliamentary Reports, Dec. 2, 1927. 
minister in 1928 that he had handled four thousand cases since 1923, ${ }^{96}$ administrative agencies in Germany continued to be subject to pressure by powerful commercial groups. Thus, the Frankfurter Zeitung reported in $1931{ }^{97}$ that in order to obtain a wage reduction the RheinischWestfaelische Kohlen Syndikat threatened to block extension of the cartel, notwithstanding government insistence upon the desirability of the latter as a means of protecting small concerns from sudden lowering of prices; and that these small concerns themselves urged the government to concede in the matter of wages, if only to preserve the cartel for their benefit.

Power to permit membership withdrawal. Closely allied to the power to dissolve cartels was the power to permit termination of cartel membership; for clearly if a sufficient number of members were authorized to cancel their cartel obligations, the cartel agreement itself must fall. The numerous examples of commercial pressure did not seem to dissuade European legislatures from supporting, in theory at least, a system whereby the individual was expected to seek this authorization in his own protection, and by so doing assume the role of prosecutor in the public interest, though the government itself had failed in that role. Such was the system governing cartel membership cancellations established by Yugoslavian and German law. If the terms of membership proved unsatisfactory, under the former law ${ }^{98}$ cancellation was procurable by application to the ordinary courts. In Germany such withdrawal was in order if "economic freedom . . . [was] unreasonably restricted." "99 But so much did the German law regard the individual or corporate member of a cartel the vindicator of the public welfare, and therefore a government representative, that actions of this type, meeting opposition from cartel management, were tried not before ordinary courts but before the Cartel Court, as if the dispute had arisen in connection with licensing or other governmental regulatory devices. Once a member came before the Cartel Court, however, the familiar pattern was repeated. Only three months after its creation

96. See comments by Isay in (1928) 2 VEREANDLUNGEN DES FUENFUNDDREISSIGSTEN DEUTSCHEN JURISTENTAGES 708, 730.

97. Frankfurter Zeitung of Jan. 25, 1931, p. 5, col. 1; id. Feb. 18, 1931, p. 5, col. 1.

98. See Decree Concerning Cartels August 3, 1934, Section 15(2) [1934] A. Z. No. 190.

99. KARTELl VeroRDNuNG, $\$ 8$ provides: "Agreements or resolutions covered by Section 1 can be terminated by each participating person without notice whenever substantial cause exists.

"It shall be considered substantial cause whenever the economic freedom of the person terminating the agreement or the resolution is unreasonably restricted, especially as far as production, marketing or prices are concerned.

"In case of litigation the Cartel Court, on motion of one of the participating persons, shall decide whether the termination was permissible. The motion must be filed within a period of two weeks after the termination has been served. If the motion is not filed within this period of time the termination is considered as in effect." See supra note 39. 
the court declared ${ }^{100}$ that withdrawal from membership was not to be based merely upon a general decline in economic conditions; termination would not be permitted unless the cartel was itself responsible for such deterioration or unless the economic crisis did not equally affect all members. ${ }^{101}$ Even without this special discouragement, withdrawal by a member was always a matter of some difficulty since cartels exacted extreme loyalty from their members. The Cartel Court withdrawal rule, therefore, could not fail to impose a certain moral as well as economic sanction on those who sought to betray this primary allegiance; even the flexible character of cartel organization could not diffuse or dissipate such loyalty, nor weaken the resistance to economic change.

In its decision of May 17, 1924,102 the Cartel Court advanced still another prerequisite to membership withdrawal: "Since the cartel member objecting to the cartel price as too high, did not allege that the prices are unethically high, and since the court did not find any violation of good ethics, no right of a member to cancel his membership can be recognized." ${ }^{103}$ By this appeal to "good ethics" as a standard of price, the court failed to prevent price-fixing and a "frozen" membership from continuing to hinder a healthy adjustment of prices to changing conditions. With cancellation forbidden and cartel members themselves unable to question prices, no one had standing to do so.

The Cartel Court, reluctant to find good cause for membership termination in matters touching external relations of cartels, was more readily inclined to permit withdrawal for causes originating within the structure of the cartel itself. Typical factual conditions recognized as "good cause" included: (1) failure of cartel management to enforce discipline equally against all members of the cartel; ${ }^{104}$ (2) excessive disciplinary measures; ${ }^{105}$ (3) unreasonable membership dues; ${ }^{155}(2)$ violation by management of equal treatment rule without authorization by the original cartel contract; ${ }^{107}$ (5) violation by a member, of special privileges allowed under original contract. ${ }^{103}$ Yet even with the aid of these criteria cancellation suits frequently ended not in termina-

100. Decision of February 25, 1924 (1924) 22 FARTELL RusdschuU 92.

101. Id. at 97. The Cartel Court further stated: "Cartel members who under favorable economic conditions reap substantial advantages from their membership shall not use an unfavorable economic development as an excuse for cancellation of the cartel agreement."

102. (1924) 22 KARTELL-RUNDSCHAU 265.

103. Id. at 267-8.

104. See e.g. Decision of Jan. 31, 1928, (1928) 26 KARtelL-Runidschud 147.

105. Decision of Cartel Court, February 4, 1924, (1924) 1 E. usid G., Decision No. 5.

106. Decision of Oct. 22, 1926, (1926) 24 KARTELl-Rundecknu 593.

107. Decision of Cartel Court, Nov, 11, 1924 (Germany, January 20, 1925), 1 E. uso G., Decision No. 38.

108. Decision of Cartel Court, July 14, 1936, (Germany, October 31, 1936) 13 E. Usid G., Decision No. 394. 
tion but in buying off the aggrieved party; and good cause was more often founded upon personal animosity than upon economic necessity. ${ }^{109} \mathrm{~A}$ score of cases indulging in blackmail of this type can have accomplished little in behalf of public protection. ${ }^{110}$

Membership withdrawal and, as a consequence, cartel termination by individuals at length lost all significance due to the Cartel Court's predisposition to enforce strictly the "equal treatment of members" rule. This may be illustrated by the fact that once certain members of an industry were ordered by the Court to join a cartel, this compulsory affiliation extended to voluntary members as well, in that no one was permitted to withdraw. ${ }^{111}$ And this restriction was not a substitute for, but supplementary to, the bulwark against withdrawal previously discussed. Redress was even further debarred by the rule that members. could apply to administrative agencies only after exhausting the remedies provided by cartel by-laws. ${ }^{112}$

Reliance on the individual as the champion of public rights would seem therefore to have proved unwise. His meagre success is hardly unexpected, for it appears to have come about through a confused combination (not wholly untypical of the control system) of unformulated ideas as to what comprises the public interest, with a mistaken interpretation and application of one facet of the liberal economic philosophy. The basic tenet of the latter, and it bears repeating, is. faith in an economic order in which every individual is free to act under economic conditions affording equal opportunity. But to preserve this. freedom the utmost vigilance on the part of government is necessary. Assigning the task of preservation to the individual alone is destructive

109. See Testimony of Expert Witnesses before the Enquête Committee in 1930. VERHANDLUNGEN UND BERICHTE DES UNTERAUSSCHUSSES FUER ALLGEMEINE WIRTSCHAAFTS-

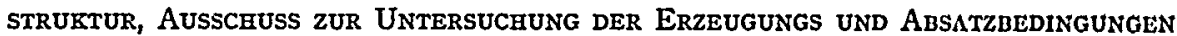
DER DEUTSCHEN WIRTSCHAFT; 1st Sub-Committee, 3rd Working Group, pt. 4, second section (1930) (hereinafter cited UNTERAUSSCRUSSES FUER ALLGEMEINE WIRSCHAFTSSTRUKTUR) passin.

110. Id. at 63 el seq.

111. Decision of Cartel Court, March 28, 1935 (Germany, May 29, 1935) 12 E. UND G., Decision No. 320.

112. Ibid. For example, where a member complained of a shift in the balance of power within the cartel, resulting from re-allocation of quotas to non-members, the Cartel Court refused termination partly on the ground that the "plaintiff [had] not used all available remedies," which included, according to the cartel by-laws, a judicial proceeding.

Apart from the question of withdrawal the sharp effect of this "exhaustion of remedics" principle (derived from the law of associations) becomes clear when it is understood that cartel draftsmen were in a favorable position to assure exclusion not only of administrative remedies but resort to the courts as well; tedress was made contingent upon arbitration, and arbitration in turn by its devious methods of enforcement could preclude judicial appeal from tribunal awards. So it might happen that a cartel member could have no recourse at all in the event of an unfair arbitration decision. See infra p. 318. Compare Decision of Oct. 22, 1914, (1914) 85 R. G. Z. 355; Decision of Amtsgericht, Berlin, June 6, 1936, (1936). 34 KARTELL-RUNDSCHAU 654. 
to the faith, since he may or may not, at his discretion, seek the remedies necessary to effect such preservation. And more particularly is this so where primary loyalties are not in the interests of society, but are procurable at a price by the very organizations which the individual is called upon to resist. It is paradoxical perhaps to complain in this instance of too much individual discretion, yet it is not a question of refusing such discretion to an individual but of insisting that the latter is too weak an instrument for adequate protection of the public. The fact remains that under the system of control, discretion is not discretion in the true sense, but merely a name for an occasion of choice which the pressure of strong groups has destroyed. Under the system of free competition contemplated by the liberal economic philosophy such pressure is an anathema, and choice and discretion are freely exercisable with but one proviso: that they shall not endanger the free contractual relation, nor disturb the natural effects of supply and demand.

\section{Judicial "Control"}

Despite the assignment to administrative authority of so large a segment of control, the civil courts, particularly the German Reichsgericht, remained free to entertain cases arising under two general classifications: suits involving (1) internal relations between cartels and cartel members or between combines and members of combines; (2) external relations between cartels or combines and any individual or corporate entity with which a monopolistic enterprise might come in contact. The essence of jurisdiction was that governments themselves through their regulatory agencies were not directly involved. And although the advent of these same agencies had radically reduced the scope of civil jurisdiction, the courts within this narrowed sphere continued as before to profess a policy of control.

\section{Internal Relations}

Cartels. It is a matter for speculation as to whether judicial regulation would have proved a greater success had it not been for the predilection of cartels for arbitration. Events lent substance to the prophecy of Franz Klein ${ }^{113}$ that judicial supervision of internal cartel relations would diminish as recourse to private arbitration increased. Settlement of disputes between members by this extra-legal means brought about the creation of a system of private tribunals, the aim of which was less the protection of individual members than the preservation of

113. See Klein [1902] 3 Verhandungen DES SECHSUndzwaNzigste: Deutechen Juristentages 299; Klein, Vorlesungen ueber die Praxis des Civilgaceesses (1900) 13-16. 
power in the hands of cartel management.114 Through the exercise of almost wholly unsupervised power, tribunals imposed fines, allowed damages, and even decreed exclusion of members from cartels. A1though aggrieved members had at their disposal several means of combatting unjust arbitral awards, ${ }^{115}$ these proved ineffective as the few cases fortunate enough to reach the courts have shown. ${ }^{110}$ The inequitable character of awards may be traced to not infrequent partiality of tribunals, a weakness hardly surprising where arbitrators themselves have had official connection with cartels involved in the proceedings. In 1938, the German Kammergericht ${ }^{117}$ denied recovery to a defendant who had been "indicted" before a tribunal by a cartel management corporation for underselling the established cartel price. Notwithstanding the defense that the corporation had unlawfully appointed as tribunal judge a member of its own board, and that the same member representing his corporation had himself negotiated with the defendant in connection with the now questioned price scheme, the court found the tribunal personnel entirely competent. Admittedly the task of determining the degree of interest necessary to require exclusion of a tribunal judge is considerable, but English as well as German courts have shown little hesitation in approving for such posts the appointment of trade association members and other interested parties. ${ }^{118}$

Judicially unsupervised arbitration has also promoted to a certain extent injustices arising from its compulsory nature. And this has proved particularly unpalatable in Germany in conjunction with the administrative power of the Reichswirtschaftsminister to compel business concerns to join cartels. ${ }^{119}$ In the decision of November 22, 1937, the Reichsgericht ${ }^{120}$ rejected the plea of a cartel member who claimed

114. For discussion see Kronstein, Business Arbilration-Instrument of Privale Government (1944) 54 YALE L. J. 36. Pursuant to statutory authority, clauses providing for arbltration of disputes were frequently made part of the cartel agreement.

115. Among these are the following:

1) Filing objections in the civil courts (a) with reference to personal competence of arbitrators, particularly where the latter have been appointed by cartel management; (b) against petitions to declare arbitration tribunal awards judicially enforceable;

2) Requesting the civil courts (a) to pass upon the validity or invalidity of the arbitra. tion clause (before action by the tribunal), regardless of the validity of the agreement to regulate markets; (b) to determine that an award already rendered by a tribunal is without effect. See Cohn, Commercial Arbitration and the Rules of Law-A Comparative Study (1941) 4 U. OF TORONTO L. J. 1.

116. See Kronstein, supra note 114, passim.

117. Decision of February 4, 1938, (1938) 36 KARTELL-RundsCHAU 416.

118. See E. E. S. Brian Smith, Ltd., v. Wheatsheaf Mills, Ltd., [1939] 2 K. B. 302; and Decision of Feb. 4, 1938 (Kammergericht), (1938) 36 KARTELL-RUNDSCHAU 416, 417.

119. See amendment of the Kartell Verordnung by decree of July 15, 1933 [1933] REIcrssGESETZBLATT I, 487.

120. (1937) 35 Kartell-Rundschau 137. 
that although compelled by administrative decree to join a cartel, he was not similarly compelled to submit to arbitration. Denial of recourse to courts under such circumstances thus strengthened the position of tribunals as a type of extraordinary court.

Moreover, self-enforcement of tribunal awards by threat of exclusion, so intimidated cartel members generally that even the procedural right of appeal from awards on the ground of improper hearing or inconsistency with substantive law ${ }^{121}$ were seldom resorted to. ${ }^{122}$ An Oberlandesgericht Muenchen decision ${ }^{123}$ is illustrative of the few appeal cases extant. Ordered by a tribunal to pay a contractual fine for violation of cartel established-prices, a cartel member objected that compliance with the award was impossible without contravening the provisions of a price statute. Yet the court affirmed the tribunal decision on the technical ground that while the tribunal undoubtedly had knowledge of the statutory prohibitions, its findings failed to state the existence of any discrepancy between the award and the law, and that consequently it was not possible to discover whether the decision was or was not affected by knowledge of such discrepancy. The basis for sustaining the pronouncement of the tribunal appears to have been the importance of safeguarding its prestige, as was shown in a later case ${ }^{124}$ which approved an award for fines though no fault was found in the defendant member.

To the same end the Reichsgericht did not find cause to reverse even a tribunal decision unfavorable to a cartel management which had professed a liberal and public-spirited position. The wire association cartel, one of the largest in Germany, was involved in a case having to do with assignment of production quotas. ${ }^{125}$ Prior to the creation of the cartel, a firm which subsequently became a member had, in derogation of the association charter as finally approved, purchased the entire production quota of a competitor. ${ }^{120}$ Notwithstanding the cartel management's insistence that the purpose of modern cartels was to enlarge rather than to curtail production and that a quota assignment requiring the closing of plants served only to restrict production, the Reichsgericht affirmed the tribunal award against the management,

121. Under certain of the European codes of Civil procedure an appeal from amards of arbitration tribunals to the civil courts is permitted on these grounds. See e.g. France and Belgium: CODE DE PROC. CIv. $\$ \$ 1023-1028$; Suter, Der Scliedsrertrag rach selucrizeriscic Zivilprozessrecht (1928) 47 ZEITSCHRIFT FUER SchweIzERIsches Recur 8, at 45, n. 140; Cohn, Commercial Arbitration and the Rules of Law-A Comparatire Study (1941) 4 U. o: Toronto L. J. 1, 4-5.

122. Kronstein, supra note 114.

123. Decision of February 13, 1939. (1939) 37 KARTELL-Rundschat 283.

124. Decision of Sept. 15, 1939. (1940) 38 Kartell-Rurdoscanu 212.

125. Decision of the Reichsgericht, March 24, 1936. (1936) 12 HoEcustrichiencicae

RECHTSPRECHUNG, No.910.

126. The charter, however, approved purchase of quotas from members. 
with the observation that the general trend of cartels and the quota system being in the direction of restriction, the tribunal could not be held in error for having concluded that this cartel was moved by the same considerations.

Although judicial cases involving tribunal decisions were remarkably few, the cases not preceded by awards were even fewer. The brief glimpse afforded by German reports reveals the same supremacy of cartel management at the expense of members and of the public generally. The Reichsgericht decision of February 21, 1933,127 illustrates the lengths to which purposeful confusion of the public was carried. A cartel member had been charged with underselling the cartel price, the plaintiff management objecting that the lower price, in so far as it affected other members of the cartel, amounted to "unfair competition." The evil in this, in the opinion of the court, rested in the fact that the public might be led erroneously to believe that the low priced member was the most efficient. And to prevent such an outcome judgment was given in favor of the plaintiff. The standard of "unfair competition" employed here, as pointed out by Franz Boehm, was not one to protect the principles of a liberal economy, but rather to oppose any step which might be contrary to prevailing business attitudes; ${ }^{128}$ indeed, statutes ${ }^{129}$ created for the purpose of curbing unfair competition had gradually come to perpetrate it.

It may not be denied, however, that under like circumstances cartel members occasionally met with success. In one instance a cartel member successfully pressed his claim before the Landesgericht Muenchen, ${ }^{130}$ declaring he had been discriminated against in the matter of cartel dues. The court ruling in his favor held that he had been unlawfully charged 100 R.M. in excess of the customary annual sum levied upon members of equal standing; that such disparity in treatment by cartel management directive could not be tolerated, except by express direction of the cartel charter itself. Despite this instance, however, and despite professed adherence to the ideal of control, the courts made little headway. And the advent of the administrative agency, by removal of some of the weight of responsibility, seems to have accelerated rather than retarded the rapidity with which the courts undermined what little there remained of the liberal economic system.

Combines. The fact that administrative control of combines, unlike

127. (1933) 31 KARTELL-RUNDSCHAU 289.

128. For discussion of the relation between the law of cartels and of unfair competition see Boehu, Wettrewerb und Monopolkampp (1933) 124 et seq.; Callahan, Der unLAUTERE WETTBEWERB (1932) 105-06.

129. See Reichgesetz gegen den unlauteren Wettbewerb, June 7, 1909 [1909] RE1cusGESETZBLATT I, 499 .

130. 156 R.G. Z. 101 (Nov. 2, 1937); (1938) 36 KARTELL-RUNDSCHAU 560. 
the control of cartels, met with but slight practical application, ${ }^{131}$ left more unreservedly to the courts the supervision of internal relations between combine members. In Germany, the decree of 1923 had little effect upon the continuous combine development begun at the turn of the century. ${ }^{132}$ At the outset, the power of management was somewhat less arrogantly felt than was the case with cartels. This was due perhaps to the more vigorous preservation in a combine of the individual legal entities. In the horizontal structure of a cartel, the individuality of its components is lost in the singleness of purpose of the cartel agreement, while in the looser vertical structure of a combine, members continue to operate with comparative freedom within a given field and without loss of corporate, partnership or other legal identity; as a result, their effectiveness in court is not completely lost.

Whatever the cause, judicial attitude toward internal combine disputes was generally strict some twenty-five years ago, encouraging the application of the several weapons of defense which combine members had at their disposal. The chief among these was the minority stockholders' suit, which not only protected, as it governed, the corporate acts of members, but served also as a channel through which the public interest itself might be represented. Before the excessive. concentration of German economic power, an additional weapon was the rule that one corporation could not assume preponderant control over another. Pursuant to this rule, the Reichsgericht ${ }^{133}$ declared void a contract between Standard Oil Company and Deutsche Petroleum Verkaufsgesellschaft, according to which the former, in consideration of an annual guaranteed profit of twenty per cent, took over all sales transactions of the German firm. In the view of this opinion, a corporation might dissolve itself, but as long as it existed it could not relinquish its individual freedom to do business. Although no mention was made of monopoly, it was doubtless an issue in the minds of the judges in the case, for petroleum monopoly was a crucial question before the legislature at the time the decision was made. ${ }^{134} \mathrm{Had}$ the principle here asserted survived sufficiently to influence the subsequent development of economic concentration, the pattern so clearly traceable in the realm of cartels might not have found its companion in the realm of combines. The "emasculation "theory," however, rather than itsopposite enunciated in the Standard Oil case, soon became the rule and the courts could not or would not check its wide acceptance. Events directed the emerging law in a fashion which courts, confronted with single specific cases, could not have been expected to foresee; they could not have foreseen that control of one corporation by another,

131. See supra note 55.

132. See supra p. 304 and note 39.

133. Decision of May 27, 1913, (1913) S2 R. G. Z. 30S; see Hoeniger Innergesellsebaft und Innensyndikat (1921) S4 ZETTSCBRIFT FUER DAS GESNuTE HANDELS-UNiD KONEURSRECH 459.

134. See Drucksachen des Reichstag (1912). 
once recognized, would in the end affect other questions of law relating to the internal structure of combines, including the power of minority stockholders to resist dominance by corporate combine management.

The Reichsgericht, indeed, had already indicated in the Hibernia case ${ }^{135}$ its predisposition towards the interests of combine management as against minority shareholders, although the effect of this decision may have been mitigated by the Prussian government's ownership of the majority shares, a fact tending to obscure the issue of public interest. The minority shareholders had protested the actions of the majority and of the management of the Hibernia Corporation in bringing about its union, as a subsidiary, with a large industrial combine. The Reichsgericht gave judgment in favor of the majority, but not without observing that the minority shareholders' endeavor to preserve the separate earning capacity of a successful and long profitable enterprise was eminently justified. Nevertheless, the court felt that in the ensuing dispute between majority and minority interests "the majority [was] perfectly entitled, when successful in its struggle, to utilize its property for purposes it considered the most important." 136 In relinquishing in this way complete control to the majority interests, the court appears not to have considered the logical consequence: that where such unbridled power is, through majority shares, ultimately centered in the hands of combine management, the management should be obliged to furnish the same measure of respect for the economic interests of the corporations over which it presides, as may be claimed for the protected property right of an individual. But combine management succeeded in evading these obligations largely by shrouding its activities in secrecy and preventing shareholder and public alike from learning the details of its plans. The Reichsgericht declared in the Goodhard case, ${ }^{137}$ that the management of a parent corporation is not bound to answer questions relating to the commercial enterprises of subsidiaries; the subsidiary, although its shares are owned by the parent corporation, remains an independent entity. ${ }^{138}$ In due course a rationale in support of decisions so advantageous to management was produced. The courts readily adopted the dictum of Rathenau: ${ }^{139}$ that combine management must be protected against interference by minority shareholders for the reason that large business associations, upon which the fortunes of countless employees and consumers depend, have themselves come to be the true depository of the public interest. ${ }^{140}$

135. (1908) 68 R.G.Z.31\%.

136. Tbid.

137. (1927) 115 R. G. Z. 332.

138. Seeid. at 338-9.

139. Rathenat, Von Kossirenden Dingen (1917) 142 et seq.

140. See also Haussarann, Vom Aktienwesen und vom Aktienrecht (1928); Berle and Means, Tue Modern Corporation and Private Property (1940). 


\section{External Relations}

Cartels. The relations of cartels with the public in general are the test of monopoly control, for there the issues are most plain and the power or weakness of the courts most fully revealed.

In a larger measure than was necessary in the case of internal disputes, the courts in Germany had to relinquish their authority to administrative bodies, so numerous were the cases involving licensing or other features of public law exclusively within administrative jurisdiction. Nevertheless, a few external relationship cases appeared in the courts after 1923. These exhibited the customary distinction between good and bad cartels, the hallmark of judicial weakness. Disputes centered around building construction bids, in connection with which the concerns or agencies issuing invitations for bids charged bidders with cartel conspiracies. That the Reichsgericht's view was as consistent in external matters as it had been in internal affairs is shown by the decision of December 6, 1935: ${ }^{141}$

"If any understanding between bidders has no other aim but to protect the parties against a form of competition which may threaten the character of bids for public works, against reckless underbidding, it does not lead to harmful price increase and is to be considered lawful." 142

More often, however, European courts had to deal with questions of legality or illegality of specific cartel measures against non-members. In 1936, the Swiss Bundesgericht ${ }^{143}$ approved a tobacco merchants' association boycott aimed at compelling the plaintiff to join the cartel. ${ }^{144}$ The court drew a somewhat tenuous distinction between compulsion for destructive purposes and compulsion as a means of inducing "coöperation": it was not the intention of the association to destroy the plaintiff by boycott, but to induce it to coöperate with the cartel in "improving" the price conditions of the retail trade, an unquestionably legal objective. The opinion states:

"The aims of the association were of such high standard that the sacrifice which the plaintiff may have been called upon to make, as a result of measures taken by the association against

141. (1936) 7 HOECHSTRICHTERLICHE RECHSSPRECHONG No. 457.

142. Ibid.

143. Schweiger-Hauser gegen Schweiz. Tabakverband (Feb. 12, 1936), [1936] B. G. E. II, 97, 104-107.

144. It should be noted that under the Swiss law, boycott approval came under the jurisdiction of the civil courts, and was not, as in Germany, subject to license by administra-

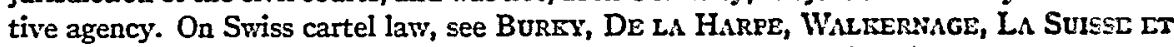
L'AUTARCIE (1939); HeUSER, CoNtroL OF INTERNational TraDE (1939). 
him, is certainly not unreasonable compared with the importance of the ends of the association." 145

To the same effect was a subsequent decision ${ }^{146}$ in which both the public's and the cartel's aim in market regulation was declared identical, and refusal to coöperate was therefore held hostile to public interest. Those willing to coöperate thus became the prodigals and individualism characteristic of the liberal economy commanded no protection under Swiss law.

Some realization of the direction in which such decisions would ultimately lead-for these Swiss cases were typical ${ }^{147}$-is to be found in French ${ }^{148}$ and German ${ }^{149}$ decisions following the great crisis of 1929. In the Duesseldorf filling station case, ${ }^{150}$ for example, a German national gasoline cartel, after fixing the wholesale prices for filling station sales, was confronted by a station owner (supplied by a cartel member) who found it more profitable to undersell the cartel price. In retaliation the cartel instructed all local stations to undersell the offender. But the latter sought judicial redress and secured the desired protection through a decision which represents one of the last judicial protests against "the brutal will to destroy." ${ }^{151}$ More especially, the decision attempted to designate "unfair" not as a preordained standard set up by cartels, but as a name to be applied to any activity directed toward interference with free competition. Nevertheless, the case was only sporadic in its effect, and failed to prevent the two Swiss Bundes-

145. See supra note 143.

146. Berner Schachtelkäsefabrik A. G. und Fromagerie Le Castel, S.A., gegen Schwcizerische Käseunion (Oct. 6, 1936) [1936] B. G. E. II, 276, 280-1.

147. Compare Decision of the Reichsgericht, February 21, 1933, (1933) 31 KarTzLLRUNDSCHAU 289.

148. See Ami du Peuple, Cour de Paris, April 9, 1930, [1930] Gaz. PaL. I, 928; Decision of February 7, 1934, cour de Lyon [1936] GAz. PAL. I, 862.

149. Decision of Oberlandesgericht, Cologne, February 1, 1935 (1935) 33 KARTELLLRUNDSCHAU 824.

150. Decision of Dec. 18, 1931 (1932) 134 R. G. Z. 342. See Isay, Der Vernichtungszweck im Weltbewerb (1929) ZEITSCHRIFT FÜR GEWERBLICHER RECHTSSCHUTZ UND URHEDERRECHT 1369 et seq.

151. A fuller statement by the Court of Appeal in Duesseldorf reads: "The defendants, by their superior financial means, may undersell the plaintiff for quite some time. They intended to destroy the economic position of the independent plaintiff, to get an absolute monopoly throughout the country and to dominate the market without any restriction. These activities are irreconcilable with the principles of competition established by law. The whole character of the activities of the defendants is inconsistent with principles of good ethics and therefore 'unfair.' The methods of the defendants are dictated by the will to destroy. The brutal will to destroy makes the underselling an unlawful method. The unethical aim governs the behavior of the defendants to such an extent that each of the means utilized by them becomes immoral." [1930] Juristische Wechenschrift 1746. Cf. Court of Appeals as quoted in the Reichsgericht's affirming opinion, Decision of Dec. 18, 1931, (1931) 134 R. G. Z. 342 . 
gericht decisions from underwriting those precedents previously discussed, in which failure of a cartel member to sustain the cartel price was deemed "unfair competition."

Combines. With respect to the external relations of combines little need be added to the evils already described in connection vith cartels. The deterioration of conditions suitable to free, uncoerced, contractual relations would not appear to need further emphasis. Yet so unequal did these relations between combines and the general public become that in Germany courts went so far as to suggest, by way of dicta, that to insure individual protection against monopolistic power, the courts themselves would dictate the pertinent contract terms. ${ }^{152}$ But even though this suggestion was based soundly upon the general principle that courts were empowered to allow damages in the protection of persons harmed by the intentional "unethical act" of another, ${ }^{153}$ its merits were never put to the proof, since consumers and consumer organizations alike were in too great fear of combine power.

\section{'The Cartel Register}

Distinct from, yet supplementary to administrative and judicial control was the cartel register. Compilation of information relating to a variety of commercial agreements was early seen to have bearing on the degree of efficiency with which regulation or even prohibition could be accomplished. As early as 1897, and prior to the abandonment of the prohibition policy by Austria, a bill was introduced ${ }^{154}$ which sought to create a register open to public, as well as to government inspection. The purpose was to elicit information helpful to the enforcement of statutes which proscribed cartels as illegal. But during discussion of the first draft, industrial representatives ${ }^{150}$ demanded in return for submission to compulsory registration under the statute, the assurance that all cartel agreements so registered would receive government sanction and approval. This demand rapidly became the crucial issue of registration throughout Europe, ${ }^{1: 3}$ for it was clear that acquiescence would lead almost certainly to the approval of what otherwise would have warranted censure. ${ }^{157}$ As Klein pointed out, if the

152. See Kartellrecht $199 \mathrm{el}$ seq.

153. See Buergerliches Gesetzbuch of August 18, 1896, Section 826. For diccusaion, see

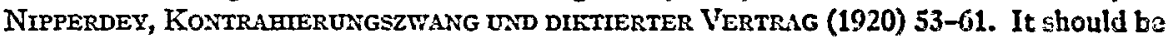
noted in this connection that under the Civil Law specific performance is the rule and damages the exception. See Gerurus Crvil Code (Wang's trans. 1907) art. 249, $\$ 1$.

154. June 1, 1897. No. 188 of the Beilagen zu den Stenographischen Protocolle des Abgeordnetenhauses. See Baudigartner-ileszlem, Kartelle und Trusts (1906) 316.

155. See Grunzei, Ueber Kartelde (1902) 190.

156. Id. at 161 .

157. See e.g. Yugoslavian Statute of August 3, 1934 as amended by the decree of November 25,1935 . Section $2(3)$ provides: "Only cartel contracts, cartel agreements or cartel 
purpose of registration was to dispel ignorance surrounding the function of cartels, it could not follow that approval, supposedly based on facts revealed, was justified before those very facts were fully examined. ${ }^{158}$

But where the legality of cartel agreements was not in issue, where as in Norway, for example, the register served as a fact-finding aid to administrative and judicial "control" rather than as an adjunct of prohibition, cartel proponents were not in a position to utilize the register to their own advantage and in consequence attacked it as an encroachment upon liberties of industry. ${ }^{169}$ But such an attitude was not always consistently held. It is ironic that as long as the alternative to control and registration was the maintenance of a status quo which allowed cartel function without interference, cartel proponents were opposed to either of these devices. But as soon as the alternative suggested became not "control" but prohibition (as if the antitrust policy of the United States were extended to international cartels) then the register became favored by such men as Lord McGowan of Imperial Chemicals, Ltd.; it was now regarded the lesser of two evils.

It was a lesser evil because it could be mitigated. Indeed, it is questionable whether it was ever an evil at all, for although the register called for statistical compilations, not a single conviction for failure to comply with its requirements appears to have been made or sustained in Europe during the interval of the two wars. The reason lay not wholly in the lack of assiduousness with which cases were prosecuted. It lay to some extent in the same indefiniteness as to the scope of statutory provisions which had afflicted legislative establishment of administrative agencies. Attempts were made to set up objective criteria for registration. Obligation to register was restricted in one instance to agreements which effected a price increase, 160 and in another, extended to all international agreements made by specified types of legal entities: corporations, partnerships and the like.101 But even these criteria appear to have failed to define the scope of application with sufficient clarity. For while it may have been possible for

understandings which are in writing and which are submitted for registration have legal validity" (emphasis supplied). See stipra notes 56 and 57.

158. Klein supra note 24 at 307 , stated: "Do not forget that the request for publication necessarily implies the recognition of the validity of the cartels, but it accomplishes nothing in the direction of obviating the dangers of the cartel development. Legal recognition is the most fundamental right the state can give. Shall the state grant this gift only for the purpose of statistics. . . . One cannot say: I do not know how cartels work or whether they should be controlled. I shall have to find that out; but nevertheless I shall recognize their validity in advance."

159. See UNTERAUSCHUSS FUER ALLGEMEINE WITSCHAFTSSTRUETUR 32 et seq.

160. See testimony of Mr. Kraetzig, UNTERAUSCHUSS FUER ALLGEMEINE WIRSTSCHAFTSSTRUKTUR 47; VON BECKERATH, DER MODERNE INDUSTRIaLISMUS (1930) $270 \mathrm{et} \mathrm{seq.}$

161. Testimony of Mr. Neumann, op. cit. sttpra note 160, at 256. 
government officials to determine the extent to which a given agreement did or did not interfere with prices and general market conditions, the single industrialist who was required to register could not tell in advance whether a particular agreement would come within the mandate of the statute. Moreover, as reported by a leading French legal society, ${ }^{162}$ lack of clear definition not only hindered efficient reporting of cartel activities, but also left the way open to accumulation of unnecessary and cumbersome data. Where a definition proved too general, states the report, "Every simple understanding of a duration of only a few days or weeks, every contract whether significant or not, every agreement between parent corporation and subsidiary, as well as decisions of syndicates ... . [had to] be published." 103 The entire register thus tended to become burdened with information of little practical value to the purposes of "control."

Registration statistics, as revealed by the several nations possessing similar register statutes, would also seem to substantiate characterization of the register as a lesser evil, since purposeful evasion appears to have been readily accomplished. Despite the cartelization of almost all branches of industry during the nineteen twenties, the Control Office of Norway could report in 1931 only 192 cartel agreement registrations and the registration of 51 "understandings." 104 And while official German statements revealed considerably more, three thousand cartel agreements in 1930, ${ }^{165}$ these were hardly commensurate with actual industrial undertakings during that period. Indeed, cartel management seems to have forwarded successfully its own purposes less by formal "registered" contract than by word of mouth negotiation, and by custom designed to actuate operations independent of written agreements. ${ }^{166}$ This device may prove particularly successful where a number of firms operating in the same field agree to confine their own markets to domestic areas, thus establishing an informal international quota system. Moreover, most private market restrictions are not founded upon a series of specific agreements, but upon central control of certain strategic materials by a single combine or group; the restrictions which flow from this authority are informal arrangements rather than contracts.

Although registration as it developed generally in Europe served only as a slight impediment, if any, to the perpetual unrolling of cartel and combine power, it seems still to warrant defense as an institution.

162. Société d'Étude Législatives. See supra note 46.

163. Ripert, cited supra note 46 , at $259-60$.

164. Andersen, Die Aufsicht ïber Trusts und Karlelle in Norcege (1933) 31 Kinten RUNDSCHAU 77.

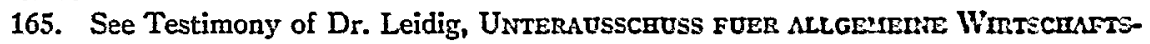
STRUCKTUR 58; VON BECKERATE, loc. cit. supra note 160.

166. Compare Norwegian industrial licensing case, supra p. 30 s. 
Conceived as a means of fact-finding and not of legalizing what was otherwise illegal, the register could have been successfully allied, in the interests of prohibition, with groups of government experts organized to investigate each field of industry. Staffs employed to examine import-export statistics, the flow of technology, and types of foreign and domestic production, could have reduced considerably the tendency of the register to become the collection of useless paper of which Meinhardt complains. ${ }^{167}$ And if to this had been added the power of government to investigate private commercial documents, where necessary in the public interest, a more vigorous government policy either of control or prohibition could have been established. As it was, government investigative authority was permitted in Germany, ${ }^{168}$ but information so obtained was not linked to any broader system of research such as is suggested here, nor was it free of certain restrictions in regard to publication.

It is in this very matter of publication and consequent publicity that the register and the suggested system of research could serve its most useful purpose. Public opinion is a healthy deterrent to schemes inimical to the public interest. An amply supply of facts would do much to eradicate the view that the operations of cartels and combines are mysterious. ${ }^{169}$ In the United States, publicity might have overcome general public apathy and misconception regarding the real nature of pre-war international monopolies, in which a considerable part of American industry was engaged. ${ }^{170}$ In actual European experience, however, registration served as a means of enhancing the power of monopolies rather than as an aid to their control.

\section{"Control" Leads Through Anarchy to Totalitarian Economy}

Notwithstanding the facts revealed in the foregoing exposition, cartel sympathizers have not been deterred from reaching the conclusion that the residuum of control still provides a more orderly economic system than could be achieved through free competition. The protection of "good" cartels and combines, it is claimed, introduces a note of "reason," which tends to relieve the economic chaos induced by price variance in times of prosperity as compared with times of depres-

167. See Testimony of $\mathrm{Dr}$. William Meinhardt, UNTERAUsschuss FUER ALLGEMEINE WIRTSCHAFTSSTRUKTUR 183-4.

168. See Auskunftsplichtverordnung, July 12, 1917 as amended August 11, 1918, and by Art. 6, Par. 2 Emergency Statute of July 13, 1923, [1923] REICaSGESETzuLATT I, 723-24.

169. See StrIeder, Studien zUR Geschichte Kapitalistischer OrganisationsFORMEN (2d ed., 1925) 184 et seq., especially 188-9.

170. For European cartel connections of American firms see Hearings before the Scnate Committee on Patents on S. 2303, 77th Cong., 2d Sess. (1942) pt. 6, 2621 et seq.; A uschuss zutr Untersuchung der Erzeugungs-und Absatzbedingungen der deulschen Wirlschaft, Verhandlungen und Berichte (1930) 3 DIE DEUTSCHE CHEMISCHE INDUSTRIE 94. 
sion. ${ }^{171}$ But if the failure of control by administrative and judicial means has not already shown this claim to be groundless, the economic confusion resulting from that failure would itself seem to do so.

The normal ratio in Germany of goods and raw materials to prices, for example, was disastrously dislocated. In essential products and materials, nearly all of which were cartelized, high prices vere sustained, while the products of firms permitted to continue functioning in free competition (and most of the products vere non-essentials) suffered drastic decrease in value, in one year as much as 46.34 per cent. ${ }^{172}$ Such disparity quickly reduced the number of those willing to assume the risks of free enterprise, and a frozen market ensued. It is believed in some quarters, however, that this very maintenance of cartel prices, despite a depressed market, is an indication of cartel success, a further example of "orderly" control. ${ }^{173}$ But the rejoinder is surely: success for whom? Has it not merely served to prevent a natural adaption of price to demand and preserved a price level beyond the pocket of the general purchaser? That is not to say that a disastrous drop in prices is desirable, but only that remedy by means of privately planned cartel schemes is illusory.

That the pre-Nazi, Bruening government in Germany was itself not wholly deceived in this respect-though perhaps given over largely to apathy-is shown by the decree of 1931 which declared that all cartel prices were to be reduced ten per cent or in the alternative the cartels were to be dissolved. ${ }^{174}$ In the restoration of disoriented values, little was accomplished by this means, however, as the measure was allied with a wage decrease scheme, which prevented sufficient improvement in purchasing power. ${ }^{175}$ A single decree could not relieve a frozen economy. Nor could a Price Commissioner, ${ }^{176}$ appointed in the hope

171. See e.g. International Labour Office, Intergovernagerital Cosorodity Control Agreesients, (Montreal, 1943) Introduction, xi-lviii; see also Natro:ial Faneıg: Trade Counct, Inc., Mesorandum On Regulatory Me.jumes Affecting Aurericani FOREIGN TRADE. (1944).

172. The period covered was slightly over a year, April 1930-July 1931. During the same period cartelized prices fell only $10.40 \%$. See Frankfurter Zeitung, July 26, 1931, p. 5, col. 1 .

173. See Haussmann and Ahearn, 1Fisconceptions About Cartels (1945) 60 Assenscasi MERCURY 295; Benni (and others), Reriew of the Econonic Aspctls of Sxcral Irilerrational Industrial Agreements (1930) League of Nations Publications II, Economic and Financial No. 41, especially with reference to the European aluminum cartel, at 25.

174. See Vierte Verordnung des Reichspräesidenten zur Sicherung von Wirtschaft und Finanzen und zum Schutze des inneren Friedens, Dec. 8, 1931, c. 1, § 2. [1931] ReIcrsGeSETZBlatr I, 699, 700; Frankfurter Zeitung, Dec. \$, 1931, p. 1, col. 3; id. Dec. 9, p. 1, col. 1.

175. Nevertheless, cartels acquiesced in the requisite decrease, though not without ocensional arrangements beneficial to themselves. The iron cartel went so far as to offer a fifteen percent cut to all customers promising to buy exclusively from a given firm for a two year period. See Frankfurter Zeitung, Dec. 15, 1931, p. 2, col.3.

176. See Verordnung ueber die Befugnisse des Reichskommisars fuer Preisuebernachung, Dec. 8, 1931, [1931] ReICHSGESETZBLATt I, 747-S. 
that he might succeed where courts and administrative tribunals had failed, contribute a solution. Control offices of Germany and other countries of Europe ${ }^{177}$ enjoyed the power to interfere with price structure at critical times, but it was seldom exercised. Rather was the Price Commissioner expected to contrive ways of accomplishing the aims of control, aims which the offices themselves hardly adumbrated. It was not remarkable therefore that the Commissioner succumbed likewise to the pressure of cartel power and was unable to break the solidarity of inter-cartel loyalties. ${ }^{178}$

The widespread use of sales quotas further aggravated the disturbed economic conditions, particularly as it prevented the dissolution of stock piles. In the normal unregulated economy, accumulated goods are customarily sold out as the first step in overcoming market crises. But through allocation of quotas cartels prevented this healthy adjustment, and by a consequent non-payment of interest severely curtailed banking and loan activities. ${ }^{179}$ And, moreover, the use of quotas as criteria for the extension of bank credit ${ }^{180}$ failed to induce any but the same unsatisfactory results. Technological standards, production capacity, and good will could thus no longer served as a basis for evaluating business concerns. Cartels of banks and other credit organizations restricted the flow of capital not only by high rates of interest, but by exclusionary practices based on the degree of conformity of the applicant to cartel rules; one who sold more cheaply or was condemned as an "unfair competitor" was excluded. The seriousness of these restrictions upon business enterprise needs no emphasis.

In addition, cartels easily obtained - at the expense of domestic "control" and without regard to national boundaries-the support of foreign cartels and governments. In 1931, the German nitrogen syndicate effectively removed the threat of a reduction of its high prices by referring the then weak German government to the high price policies of the Chilean government and of allied American interests with which the Chilean nitrogen syndicate was associated.181 The same device was used by French and German iron syndicates, each

177. Germany: See Karteli. Verordnung, supra note 39. Decree of July 15, 1933 [1933] Reichsgesetzblatr I, 487. Bulgaria: Statute of August 15, 1936. Norway: Statute of March 12, 1926, Gesetz betreffend Kontrolle von Konkurrenzeinschraenkungen und Preismissbrauch (1926) 24 Kartell-Rundschau 133. Roumania: Statute of May 8, 1937, Official Gazette No. 106, May 10, 1937; for German translation, see (1937) 35 KartellRundschau 385. Sweden: Statute Relating to the Study of monopolistic enterprises and combinations, June 18, 1925, see (1936) 34 KARTELL-RUNDSCHAU 223.

178. Compare supra p. 315 and note 100.

179. See Frankfurter Zeitung daily during July and August 1931, especially August 2, 1931.

180. See [Heinrich Kronstein], Zum Problem: Staat und Wirtschaftsmacht (1929-30). DIE Justrz 137; Frankfurter Zeitung, Oct. 7, 1931, p. 3, col. 2.

181. See Frankfurter Zeitung, February 15, 1931, p. 6, col. 1. 
group defeating the objectives of its own government by pointing to the high prices sustained by the other. ${ }^{182}$ It seems hardly a product of "reason" that could have brought about a situation in which control offices could neither reduce prices of finished products because imports of raw materials were subject to fixed prices, nor conversely reduce the prices of domestically mined raw materials because the products of foreign mines were sold at high prices in the domestic market.

So numerous indeed, were these symptoms of dislocation and economic anarchy that governments were forced once more to take positive steps to rehabilitate the control system, which had so patently broken down. Attempts were made first to immunize government agencies against the influence of industry. As a means to this end, and also as a supplement to price control, gorernments themselves took up the task of quota allotment. Import quotas were established through international agreement, principally by France, ${ }^{193}$ and in many cases these adhered in content and pattern to those already established by cartels. ${ }^{184}$ In the electrical industry a similar result was accomplished by alternative measures: the whole industry was required to join voluntarily by a given date a government supervised cartel, or an arbitrary quota system would become effective. By the former means the French and German electrical industries cartelized the entire electrical trade between France and Germany. ${ }^{185}$

But the passage from a negative system of control-directing what was not to be done-to a policy of positive instructions comprising dictated prices or compulsory government cartels, accomplished very little more in rescuing industry from its plight. $15 \mathrm{~s}$ What direction there was, was not based upon a clear conception of the true relation of this or previous legislation to the public interest, nor was it based upon the

182. Id. Jan. 13, 1931, p. 5 .

183. See (1932) 53 Electrotechnische Zetrschrift 191; Imternatro:ial Labour Office, INTERgovernatental Cosmodity Control Agreeurents (Montreal 1943) svi et seq.; on tariff policies in steel, see Hexner, The International Sterl Carmer (1943) 239-51.

181. An interesting example of the interrelations between international treaties and cartels in the electrical equipment agreement of 1932 between France and Germany. Under the custodianship of the two governments, the two industries established "L'Office FrancoAllemand de Matériel Électrique" which executed at one and the same time the import quota assigned to Germany by the Franco-German Commercial Treaty, and the provisions agreed upon by private industry. See (1932) 52 ELECTRoTeChnIsche ZeITECRIIFt 191.

185. (1932) 53 ELEKTRO TECHNISCHE ZEITSCHRIFr 191.

186. Of the original regulatory statutes only the Norwegian statute of March 12,1926 , Art. 14, supra note 46 , gave the government power positively to determine cartel prices and sales conditions. The Control Office, however, appears to have used this pamer only for the purpose of declaring the cartel price binding on business organizations, including those not belonging to the cartel. See [1936] TrUST KONTROLLE: 45 and 104. In only one case was there any attempt to use this power to restrict international cartels. [1937] TrOST Ko::TROLLEN $37-60$. 
principles of a free economy. Instead, it was government improvisation necessitated by the calamitous condition into which the economy had fallen. And while governments may have desired absolute mastery of all economic contingencies, they failed to achieve it owing to the lack of a well-formulated goal toward which legislation could be directed. So it was that cartels were able to perpetuate their exploitation of government weakness, particularly in Germany. There, as was pointed out by Boehm, ${ }^{187}$ the government was empowered neither by the old legislation nor the new to act until after the damage to public welfare had been done; it could in no sense act in a preventive capacity.

In the light of these facts it is not surprising that in Germany, National Socialism eventually supplied the long absent aim toward which cartel control could be directed. Totalitarianism could hardly be expected to have adhered to the principles of free competition; its aims were expressed in the prosecution of war, and with this the public good was purposely identified. By such means, "control" of a perverted sort was made effective by 1939. The rest of Europe, however, caught in the disruption of economic trends and forced along the paths to total war, was denied, at least for a time, a choice between the two alternatives: totalitarian ideals and methods, or a free market. In the midst of preparation for conflict the competitive scheme had to be sacrificed temporarily. And it must now be plain that-except for the possible suiting of a different aim to totalitarian method-there was no other choice; that control alone, lacking in guiding principle, remained and continues to remain an ineffectual compromise between those two.

\section{ConCLUSTON}

In evaluating the lessons of European legislative and judicial precedents, particularly as these may affect the United States, there is perhaps a tendency among those trained in the common law to read into the civil law of the Continent a sensitivity to constitutional prerogatives and a jealous protection of individual rights which does not exist. But although the laws of the codes and statutes may have been intended merely as outline sketches for the courts to follow, rather than as depositories of civil rights, and despite the reasonable deduction that this accounts in part for the liberties which courts and administrative agencies alike have taken with the public interest, these circumstances would not seem to remove altogether a basis of comparison between past European experience and present American problems. The warning to the United States is of significance if only because both the symptoms of weakened constitutional privileges and of inroads upon the functioning of free enterprise may be already present. ${ }^{189}$ It is

187. BOEHM, WETTBEWERB UND MONOROLKAMPF (1933).

188. See Kronstein, Business Arbitration-Instrument of Private Government (1944) 54 YALE L. J. 36. 
only with unthinking arrogance that we may say: it can't happen here. For constitutional rights and privileges must always be viewed against the background of the current economic fashion, as a comparison of the Adkins ${ }^{159}$ and West Coast Hotel ${ }^{100}$ cases amply shows. And in the molding of that fashion the power of cartels and combines is undeniable.

In the past, the Supreme Court of the United States has been at times instrumental in fostering this power. Through failure to place constitutionally derived rights in correct relation to economic change such decisions as Great Atlantic and Pacific Tea Company i. Cream of Wheat Company 191 were made possible and the evil of unequal contractual relations increased. The Court ruled that a wholesale enterprise in a dominant and controlling position could not be compelled to sell to an economically weak retailer, since ". . . a trader might reject the offer of a proposing buyer for any reason that appealed to him. . . " ${ }^{192}$ Though admittedly a technically just decision, it seems an illusory one, for the bolt was drawn long after the horse had fled. The buyer no longer stood on that equal footing which made the "trader's" rights sacrosanct. Yet the court appears to have lost to the buyer that privilege, while continuing to enforce a rule that presupposed his possession of it.

American courts have frequently shown themselves prone to follow European example in undermining legislation designed to protect free competition, ${ }^{193}$ as well as in permitting expansion of judicially un-

189. Adkins v. Children's Hospital of the District of Columbia, 261 U. S. 525 (1923). The Minimum Wage Act of the District of Columbia, regulating the hours of worl: for women, was held unconstitutional as an impairment of freedom of contract under the due process clause of the Fifth Amendment.

190. West Coast Hotel Co. v. Parrish, 300 U. S. 379 (1937). Only fourteen years Later Chief Justice Hughes speaking for the Court expressly overruled the Adhirs cass, and, in an opinion reflecting the Holmes dissent in the latter, upheld the constitutionality of a Washington Minimum Wages for Women Act. Compare Holmes' famous dissent in Lochner $v$. New York, 198 U. S. 45, 74 (1905) with the majority opinion in the eame case by Justice Peckham.

191. 227 Fed. 46 (C. C. A. 2d, 1915).

192. Id. at 49 .

193. Examples of the weakening of the principle of competitive economy by court decision are not unfamiliar to the American lawyer. In Standard Oil Co. of New Jersey v. United States, 221 U. S. 1 (1911), the Supreme Court interpreted the mandate for prohibition in the Sherman Act, 26 STAT. 209 (1890) 15 U. S. C. $\$ 1$ (1940) as admitting limitation by a "rule of reason." Even "cartelization" was permitted under spacial circumstances. According to the opinion in Appalachian Coals, Inc. v. United States, 285 U. S. 344 (1933): "Realities must dominate the judgment. The mere fact that the parties to an agreement eliminate competition between themselves is not enough to condemn it. . . . The question of the application of the statute [Sherman Act] is one of intent and effect, and is not to be determined by arbitrary assumptions. It is therefore necessary in this instance to consider the economic conditions peculiar to the coal industry, the practices which have obtained, the nature of defendant's plan of maling sales, the reasons which led to its adoption, and the probable consequences of the carrying out of that plan in relation to marlist 
supervised arbitration. ${ }^{194}$ It is not insignificant perhaps that in regard to the former, the "rule of reason" relating to trusts and combines was adopted in the United States only twelve days after a similar rule became the law of France. ${ }^{195}$ Nor that even a cursory glance at American case authority ${ }^{196}$ indicates the loss of minority stockholders' prestige through the wide acceptance of Rathenau's doctrine: the public interest is management's interest. ${ }^{197}$ It may be, indeed, that these are indications of the passing of free competition from present-day economic polity; that its revitalization is not possible. If this be so, and there is by no means conclusive proof that it is, the cure of the enormous distortion of judicial and administrative power which has so long victimized Europe and troubled the waters in the United States would still not seem to lie in more "control," but in a forthright adoption of totalitarian method; in deliberate and conscious planning for pre-determined ideals of public welfare.

But as long as the liberal economy endures its correlative would appear to be the prohibition of cartels and combines. ${ }^{198}$ It may be per-

prices and other matters affecting the public interest in interstate commerce in bituminous coal." Id. at 360-1. See Eldridge, The Appalachian Coal Case and the Rule of Reason (1933)

1 Geo. WASIr. L. REv. 513; Jackson and Dumbauld, Monopolies and the Coutt (1936) 86 U. OF PA. L. REv. 230.

194. Ironstein, supra note 188.

195. Chambre des Reguêtes de la Cour de Cassation, Decision of May 3, 1911 [1912] RECUEI PÉRIODIQUE DE JURISPRUDENCE (Dalloz) I, 33.

196. See Berle and Means, The Modern Corporations and Private Property (1940).

197. Supra note 139.

198. The following excerpt from the recent opinion of Judge Learned Hand in the Alcot case is an excellent and dispassionate resume of the problem of prohibition in the United States:

"Many people believe that possession of unchallenged economic power dead. ens initiative, discourages thrift and depresses energy; that immunity from competition is a narcotic, and rivalry is a stimulant, to industrial progress; that the spur of constant stress is necessary to counteract an inevitable disposition to let well enough alone. Such people believe that competitors, versed in the craft as no consumer can be will be quick to detect opportunities for saving and new shifts in production, and be eager to profit by them. In any event the mere fact that a producer, having command of the domestic market, has not been able to make more than a "fair" profit, is no evidence that a "fair" profit could not have been made at a lower price. . . . True, it might have been thought adequate to condemn only those monopolies which could not show that they had exercised the highest possible ingenuity, had adopted every possible economy, had anticipated every conceivable improvement, stimulated every possible demand. No doubt, that would be one way of dealing with the matter, although it would imply constant scrutiny and constant supervision, such as courts are unable to provide. Be that as it may, that was not the way that Congress chose; it did not condone "good trusts" and condemn bad ones; it forbade all. Moreover, in so doing it was not necessarily actuated by economic motives alone. It is possible, because of its indirect social or moral effect, to prefer a system of small producers, each dependent for his success upon his own 
suasively argued that though the United States favors prohibition, the rest of the world adheres to "control," viz., monopoly, with the result that American commerce, if it is to be forced to conform to the professed American policy, must suffer the harsh consequences. This contention, though true to a certain extent, has been considerably exaggerated through facile manipulation of opinion by industrial and commercial interests. In promoting monopolies in Europe these interests have referred repeatedly to the example of American monopolies, insisting that the latter are reason in themselves for continuation of the system in Europe; while monopoly sympathizers in the United States have conducted similar campaigns with reference to European cartels and combines. ${ }^{159}$ But more important, the argument obscures the unquestioned fact of American power and prestige, so greatly enhanced as a result of the war. In the face of the opportunity afforded by such power, it is well to consider how it shall best be given expression. It should not be forgotten that in the long run the ideal aims of a people prevail; that ideas shape the difference between one society and another. If, then, the United States were to abandon the idea of a free market, particularly in a time of world distress when privately planned economies (whether "controlled" or not) establish prices beyond the common means, American civil polity would surely seem to have lost one of its most distinguished and traditional characteristics.

skill and character, to one in which the great mass of those engaged must accept the direction of a few. These considerations, which we have suggested only as possible purposes of the Act, we think the decisions prove to have been in fact it: purposes." United States v. Aluminum Co. of America, 148 F. (2d) 416, 427 (C. C. A. 2d, 19:5).

199. A similar technique is applied to the promotion of commercial arbitration: compare Sub-Commission report in Internatronal Ceasmer of Cosnrence, Frrst Congress, Brochure No. 13 (1921) 15, with Gribert aNd Dickens, TNEC Rep., Exfont Prices and Export Cartels (Webb-Pomerene Assoclations) Monograph 6 (1910) 115. 